\title{
THE RECENT EFFECTS OF EXCHANGE RATE \\ ON INTERNATIONAL TRADE
}

\section{Myoung Shik Choi*}

\begin{abstract}
This paper investigates effects of the real exchange rate and its volatility on trade balance and real GDP using a set of eighteen countries, mainly the OECD developed countries. The paper reports econometric procedures and empirical estimates for major currency-owned large economies and non-major currency- owned countries. One task, for which the elasticities of international trade and real GDP are needed, is developing exchange rate assessments. The study finds that real currency depreciation leads to improvement of trade balance in most of the examined developed countries. But the trade balances after real depreciation of currency do not follow J-curve patterns. With regard to the real exchange rate variability, the evidence is mixed. Similarly, effects of the real currency devaluation on real GDP differ across countries. Also, we observe that major currencyowned countries could have different value-and-volume-effects with non-major currency countries.
\end{abstract}

Keywords: cointegration, causality, exchange rate, FX volatility, GDP, major currency, shock response, trade balance, unit root, VAR model, VEC model

JEL Classification: F31, F32, F40

\section{Introduction}

One of the conventional concerns in international economics is what the effect of exchange rate movement is on the real economy. Two main areas are the relationship between exchange rate fluctuation on international trade and on economic activity in the countries concerned. Both areas of research have a huge and growing number of publications. However, empirical evidence has established neither a clear relation between them nor a specific time-lag effect on them. One task for which the elasticities of international trade and real GDP are needed is the developing of exchange rate assessments and this paper sets out the details of estimated outcomes for this purpose.

The short-run effect of exchange rate change on trade flows or economic activity may depend upon the economic characteristics while the long-run effect of exchange rate change may rely on market distortions according to Auboin and Ruta (2011). The exchange rate change can alter relatively sticky prices and affect resource allocations depending on the invoice currency and the trade structure of Magee (1973) and Staiger and Sykes (2010). Also, the effect of exchange rate change can be significant relying on the asymmetry of information and the market failure, indicating that currency weakness

* $\quad$ Myoung Shik Choi, International Trade Department, DanKook University, South Korea (msc50355@gmail.com). 
has a positive impact on GDP growth by alleviating the costs of market distortions or a negative impact on growth by leading factor misallocations at the same time.

Numerous studies conclude that real currency depreciation leads to improvements of trade balance. First, the standard trade theory states that exchange rate change affects the value and the volume of free trade. Real currency weakness increases price competition for exports from the classical model. Also, Keynesian absorption macro-approach considers the trade balance as a function of real income and absorption. Currency weakness may have an increase in the output or a decrease in the domestic expenditure, which leads to an improvement of the trade balance as $Y-A=T B$ in the equilibrium where $Y$ is the real income and $A$ is the domestic expenditure. And monetary macro-approach indicates that currency depreciation improves the trade balance by increasing domestic prices and thus decreasing the real money supply, implying that if an expansionary money supply after devaluation meets the new money demand, the effect of currency depreciation might be preserved as Ali et al. (2014) says. Recently, Tocarick (2010) calculates how a change in real exchange rate might affect the balance of trade, and confirms that a real devaluation always improves the trade balance for a small open country, but may not for a large country that can influence the international prices of its exports or imports.

An elasticity micro-approach introduces the J-curve phenomenon with the short-run value effect and the long-run volume effect. The Marshall-Lerner condition is necessary to improve the trade balance. Currency weakness may lead to the J-curve pattern but some research does not find that time-leg effects. For the J-curve short run effect, Magee (1973) addresses the problems of currency-contract, pass-through of exchange rate, and quantityadjustment with price elasticity. Junz and Rhomberg (1973) find that the J-curve effect may take more than a year due to a certain lag of recognition, decision, delivery, replacement, and production, while Calvo and Reinhart (2002) find that exports decrease for the first eight months after currency weakness. Bahmani-Oskooee (1985) supports the J-curve movement for developing countries by using maximum 12 lags. Noland (1989) finds that the J-curve effect starts to improve the trade balance after seven deteriorated quarters in Japan. On the other hand, Backus et al. (1994) and Moffett (1989) find the S-curve effects in the long run for the OECD nations and the US, respectively.

A large amount of evidences on the effect of exchange rate variability are mixed. Hodge's (2005) survey explains that there is an ambiguous relationship between exchange rate volatility and trade. A risk-aversion standard model presumes a negative link between volatility and trade volume. Most empirical research supports the negative link as Chowdhury (1993) does for the G-7 over 1973-1990. Choudhry (2005) finds that currency volatility in the form of GARCH has a negative impact on real exports of the United States to Canada or Japan for 1974-1998. Zhao (2010) finds that currency volatility has a negative long-run impact on real bilateral exports of New Zealand for 1991-2007 in spite of a little positive effect in the short run. But this relationship may be reversed by not only the possibility of risk hedge or speculation and the third factors, but the unrealistic modelling assumptions and difficulty in the consistent findings of Clark et al. (2004). Also, Cote's (1994) paradox of a negative effect notes the lengthy lags are hardly detectable between exchange rate change, production and trade. 
It is surprising that most studies show mixed evidences on effects of the real exchange rate on real GDP. But there is a consensus in the literature that nominal devaluation, which leads to real depreciation should raise real GDP in a small open economy. Kappler et al. (2011) find that currency strength makes a strong negative impact on current accounts within three years after an appreciation event, and it decreases savings and GDP. Haddad and Pancaro (2010) describe that currency weakness can promote economic growth only in low-income East Asia's export-led countries. Similarly, Yusoff (2010) finds a delayed J-curve pattern and its same effect on output in Malaysia for 1977-2001. Also, Kohler et al. (2014) find that the effect of the exchange rate change on GDP for one or two years is smaller than the permanent effect for two or three years. By contrast, Kandil and Mirzaie (2002) suggest that currency strength increases outputs via the effect of the supply shock, while the effect of currency strength on aggregate demand is inconclusive. Berument and Pasaogullari (2003) find that real currency weakness, within the first four quarters, has a reverse impact on output in Turkey for 1987-2001.

This paper estimates effects of the real exchange rate and its volatility on trade balance and real GDP using a set of 16 OECD developed countries plus China and India. We try to divide them into 3 currency groups (e.g. vehicle major currency like US dollar, other major currency, and non-major currency-owned countries) because the set of heterogeneous countries matters for trade balance and real exchange rate dynamics in different ways and they are probably behind mixed evidence. ${ }^{1}$ This paper would be accomplished with a comparison of estimated elasticities between large economy and small open economy. We claim a value effect of one's way of currency-contracts so that major currency-owned countries may have different value-and-volume-effects with countries with non-major currencies. Section 2 reviews theoretical background. Section 3 empirically examines them. Section 4 summarizes and concludes.

\section{Theoretical Background}

The paper would like to explain how the real exchange rate and its variability can affect trade balance and real GDP. In this sense, this section is seeking to deliver clear motivation showing major signs with links to theoretical models.

The first thing to do is to use the model of Rivera-Batiz and Rivera-Batiz (1989) to explain precisely why the exchange rate and its mobility are important in an open economy and to analyse how they would affect the economy. The macroeconomic equilibrium is found where the YY and LL curves intersect. The YY curve indicates the product market equilibrium with the positive relationship between exchange rate level, exports and quantity of output while the LL curve means the money market equilibrium with

1 The group of vehicle major currency: United States. The group of other major currency: Japan, Switzerland, Australia, Canada, the United Kingdom, Germany, France, Spain, the Netherlands, Belgium, Italy. The group of non-major currency: South Korea, Mexico, Chile, Israel, China, India. And the Eurozone: Germany, France, Spain, Netherlands, Belgium, Italy.

In addition, the group of free floating regime: the United States, Japan, Australia, Canada, the United Kingdom, Germany, France, Spain, the Netherlands, Belgium, Italy, Mexico, Chile. The group of floating: South Korea, Israel, India. The group of Craw-like arrangement: China, Switzerland. 
the short-run negative relationship between exchange rate and income but the long-run curve is vertical at the natural level of output. When the economy reaches the long-run equilibrium, the expected exchange rate level will have adjusted to equal the actual exchange rate level. This implies that when some event increases money supply, the shortrun LL curve shifts to the right. The economy moves upward as the exchange rate level rises and output increases.

Also, from the approach of aggregate demand and supply, an exchange rate fluctuation, which reflects an unanticipated currency fluctuation, can cause real output change in the combination of the demand and supply sides, while an anticipated movement of exchange rate can lead to real output change in the supply side as Dincer and Kandil (2011) and Kandil (2015) indicate.

By the way, the effect of the exchange rate change on trade balance and domestic output would take several periods on a time-lag distribution. All the periods that exports, imports, and production take to adjust quantitatively, can be viewed as a time lag-interval. So, we are able to represent the lag effects by saying that economic outcome at time $t$, $y_{t}$ is affected by a change in policy variable at $t, x_{t}$ so that $y_{t}=f\left(x_{t,} x_{t-1,} x_{t-2 \ldots}, x_{t-n)}\right.$ in case of n-finite periods, which indicates the effect of $x_{t}$ on $y_{t}, y_{t+1}, y_{t+2}$, and so on. A policy maker must recognize the timing of the changes and the length of time for major effects.

We review by defining the standard model, which follows two domestic-foreign countries with imperfect substitution. Initially, the model recognize that $q=1 / q^{*}$ where $q$ is the domestic real exchange rate and $q^{*}$ is the foreign real exchange rate,

$$
\begin{gathered}
X=f_{1}\left(q, Y^{*}\right), \frac{\partial}{\partial} \quad, \frac{\partial X}{\partial Y^{*}}>0 \text { and } M=f_{2}(q, Y), \frac{\partial M}{\partial q}<0, \frac{\partial M}{\partial Y}>0 \\
X^{*}=f_{3}\left(q^{*}, Y\right), \frac{\partial X^{*}}{\partial q^{*}}>0, \frac{\partial X^{*}}{\partial Y}>0 \text { and } M^{*}=f_{4}\left(q^{*}, Y^{*}\right), \frac{\partial M^{*}}{\partial q^{*}}<0, \frac{\partial M^{*}}{\partial Y^{*}}>0
\end{gathered}
$$

Where $X$ is the domestic supply volume of exports, $M$ is the domestic demand volume of imports, $X^{*}$ is the foreign (the rest of world) supply volume of exports, $M^{*}$ is the foreign demand volume of imports, $Y$ is the domestic income, $Y^{*}$ is the foreign income, and $f($. means the function.

The trade balance can be defined by a net export as $T B=X-M=f_{5}\left(q, Y, Y^{*}\right)$ and $T B^{*}=X^{*}-M^{*}=f_{6}\left(q^{*}, Y, Y^{*}\right)$ where $T B$ is the domestic trade balance, and $T B^{*}$ is the foreign trade balance. In equilibrium, the demand and supply conditions for both regions are determined as $X-M=M^{*}-X^{*}$ and $X+X^{*}=M^{*}+M$.

Now, we introduce a settlement currency choice into international trade transactions. We move from a two-country world to three-country world with three currencies for the allowance of a third-country vehicle currency. Suppose that agents can invoice in the exporter's currency, the importer's currency, or a third-country vehicle currency such as:

$$
\Sigma_{j=1}^{3} C_{j, t}=1 \text { for all, } j \in\{E C, I C, T C\}
$$


Where $C_{j, t}$ represents a certain currency $j$ at time $t$, EC is the exporter's currency, IC is the importer's currency, and $T C$ is a third-country vehicle currency e.g. the US dollar.

In other words, the domestic trade balance can be represented by a different functional form of $T B=X\left(q, Y^{*}\right)-M(q, Y)$. If agents invoice in each one of the exporter's currency, the importer's currency, and a third-country vehicle currency on exports and imports, then the trade balance value in domestic currency is displayed in order as follows:

$$
\begin{gathered}
T B_{n, 1}=X\left(q, Y^{*}\right) \cdot P-M(q, Y) \cdot P * \cdot S \text { and } T B_{r, 1}=X\left(q, Y^{*}\right)-M(q, Y) \cdot q \\
T B_{n, 2}=X\left(q, Y^{*}\right) \cdot P * \cdot S-M(q, Y) \cdot P \text { and } T B_{r, 2}=X\left(q, Y^{*}\right) \cdot q-M(q, Y) \\
T B_{n, 3}=X\left(q, Y^{*}\right) \cdot P * \cdot S-M(q, Y) \cdot P * \cdot S \text { and } T B_{r, 3}=X\left(q, Y^{*}\right) \cdot q-M(q, Y) \cdot q
\end{gathered}
$$

Where $T B_{n}$ is the trade balance value in nominal term, $T B_{r}$ is the trade balance value in real term, $P$ is the domestic price, $P^{*}$ is the foreign price, $S$ is the exchange rate, $q$ is the real exchange rate $\left(q=S \cdot P^{*} / P\right), 1$ means invoice in the exporter's currency $(E C)$, 2 means invoice in the importer's currency $(I C), 3$ means invoice in the third-country vehicle currency $(T C)$.

The exchange rate change has an effect on the trade balance via the channels of exports and imports. If the exchange rate changes in value, then the changes of the real trade balance are:

$$
\begin{gathered}
\Delta T B_{r, 1} / \Delta q=\Delta X\left(q, Y^{*}\right) / \Delta q-\Delta M(q, Y) \cdot q / \Delta q-M(q, Y) \\
\Delta T B_{r, 2} / \Delta q=\Delta X\left(q, Y^{*}\right) \cdot q / \Delta q+X\left(q, Y^{*}\right)-\Delta M(q, Y) / \Delta q \\
\Delta T B_{r, 3} / \Delta q=\Delta X\left(q, Y^{*}\right) \cdot q / \Delta q+X\left(q, Y^{*}\right)-\Delta M(q, Y) \cdot q / \Delta q-M(q, Y)
\end{gathered}
$$

Where $\Delta$ indicates the rate of increase operator. In addition, $\Delta T B_{r, 4} / \Delta q=\Delta X\left(q, Y^{*}\right) / \Delta q$ $-\Delta M(q, Y) / \Delta q$ in case of the invoice in the domestic currency. These equations imply that each change in the real trade balance may have different volume effects with diverse adjusting lags due to the different value effects according to one's way of currencycontracts.

Furthermore, the J-curve pattern is attributed to a time-lag adjustment of quantity to relative price change. Magee (1973) divides it into three parts of currency contract period, pass-through period, quantity-adjustment period. The first step is to consider the currency contract just after currency devaluation for the value effect. The second step is to consider the pass-through of relative price in a brief period after currency weakness in which assumes a fixed quantity for the value effect. The third step is to consider the quantity-adjustment in a long period after currency depreciation for the volume effect as the Marshall-Lerner condition. 
We should like to end by saying this. Effects of the real exchange rate variability on trade might be questionable due to two reasons. First, developed financial markets allow participants to hedge against the exchange rate variability. In this regard, most of the countries in the study sample experience well developed financial system. Second, the real exchange rate variability can be driven not only by the nominal exchange rate changes but also by price level changes, both domestic and foreign. For example, while supply shocks (shocks to price levels) are short lasting, productivity shocks or terms of trade shocks might exhibit persistent effects on macroeconomic variables and consequently trade balances. These driving forces have probably different implication to trade balance as they are driven by different shocks. A structural dynamic stochastic general equilibrium model would be able to capture different shock types.

\section{Empirical Models}

This section employs the existing literature to formulate empirical models. There is a vast literature on effects of real exchange rate depreciation on the trade balance and the output. Our first interest is exploring the response of the trade balance to the exchange rate change at the aggregate level. The long-run relationship of the trade balance and the exchange rate will end up with the following model based upon Zhao (2010) and Petrovic and Gligoric (2010):

$$
T B_{t}=\alpha+\beta_{1} X_{t}+\beta_{2} Y_{t}+\beta_{3} V_{t}+\varepsilon_{t}
$$

Where $T B_{t}$ is the log of real trade balance, which is real exports divided by real imports at time $t, X_{t}$ is the log of real effective exchange rate at $t, Y_{t}$ is the log of domestic real gross domestic product at $t, V_{t}$ is the $\log$ of real effective exchange rate volatility at $t$, $\varepsilon_{t}$ means the disturbance at $\mathrm{t}$, and $\alpha$ is the constant. $\beta_{1}, \beta_{2}$ and $\beta_{3}$ are the coefficients that measure the effect of $\Delta X_{t}$ or $\Delta V_{t}$ on $\Delta E\left(T B_{t}\right)$, all other things held constant where $\Delta$ is the rate of increase operator and $E$ is the expectation operator. Additionally, a real effective exchange rate can be a better indicator for the economy because it focuses on the business cycle movements between real exchange rates and other aggregate variables, providing a measure of purchasing power of a foreign currency relative to its domestic purchasing power.

Non-stationary time series are cointegrated if a linear combination of these variables is stationary. This long-run elasticity equation of the trade balance includes the term of GDP for controlling the effect of domestic income, and includes the constant term for capturing the trending characteristics. We estimate the effect of the exchange rate change on the trade balance with the hypotheses of positive-signed $\beta_{1}$ in case of exchange rate appreciation and of negative $\beta_{3}$ in case of rising volatility. The hypothesis of positive $\beta_{1}$ in case of currency depreciation implies that the Marshall-Learner condition is satisfied. The sign of $\beta_{2}$ is ambiguous because the GDP's increase can help export more or import more.

Cointegration implies that a constrained error-correction model (ECM) can be applied. If there is cointegration, a vector error-correction model (VECM) is used for the estimation. If there is no cointegration, the vector autoregressive (VAR) model is 
used for the estimation by using the first difference variables. Thus, we derive the trade balance equation written as an ECM of Engle and Granger (1987) from the long-run equilibrium relationship above.

$$
\Delta Z_{t}=a+b_{1, i} E C T_{t-1}+b_{2, i} \Sigma_{i=1}^{k} \Delta X_{t-j}+b_{3, i} \Sigma_{i=1}^{k} \Delta Y_{t-j}+b_{4, i} \Sigma_{i=1}^{k} \Delta V_{t-j}+b_{5, i} \Sigma_{i=1}^{k} \Delta T B_{t-j}+u_{t}
$$

Where $Z=(X, Y, V, T B)$ is the first difference operator with $X=$ the real effective exchange rate, $Y=$ the real GDP, $V=$ its volatility, $T B=$ the real trade balance. $E C T_{t-1}$ is the error-correction term at time $t-1, X_{t-j}, Y_{t-j}$ and $V_{t-j}$ are the lagged values of explanatory variables, $u_{t}$ is the vector of residuals assumed serially uncorrelated, $b_{2, i}, b_{3, i}, b_{4, i}$ and $\mathrm{b}_{5, i}$ are the unknown distributed lag coefficients with $i=4, \mathrm{k}$ is the finite lag length, $\Delta$ is the difference operator, and $\Sigma$ indicates the lagged summation. The coefficients of the regressors indicate the effects in the short-run and they become zero in the longrun. $E C T$ is the residual from the co-integrating regression equation, i.e. $E C T_{t-1}=T B_{t-1}$ $-\beta_{1} X_{t-1}-\beta_{2} Y_{t-1}-\beta_{3} V_{t-1}$ with $\beta_{1} \beta_{2}$ and $\beta_{3}$, the long-run coefficients between $X, Y, V$, and $T B$. The short-run coefficient $b$ represents the short-run interaction between the trade balance and its determinants. The $b_{1}$ captures the short-run adjustment of each variable toward the long-run equilibrium value so that $b_{1}$ presents the proportion of the short-run disequilibrium in the trade balance in one period being corrected in the next period. That is, $b_{1}<0$ implies a stable adjustor.

For a short-run relationship, impulse response functions enable us to track the evolution of either the trade balance or GDP to exchange rate shocks, which are supposed to die out after several periods. The impulse response functions are computed from the reduced form of the VAR model. The impulse response represents whether real currency shocks lead to pro-cyclical short-run variations in the trade balance and the output. The estimated impulse response will be consistent with the behaviour of the trade balance and the output.

Let us consider that a structural VAR model is $A Z_{t}=B(\mathrm{~L}) Z_{t-1}+\varepsilon_{t}$. Then, the reduced form of VAR model estimable with data is:

$$
Z_{t}=C(\mathrm{~L}) Z_{t-1}+u_{t}
$$

Where $Z_{t}=(X, Y, V, T B)_{t}$ is the vector of variables of dimension $i=4$ at time $t, B(\mathrm{~L})$ is the matrix polynomial in the lag operator $\mathrm{L}, \mathrm{A}$ is the coefficients matrix, $\varepsilon_{t}$ is the vector of structural shocks uncorrelated with each other, and $u_{t}$ is the vector of reduced form residuals. This indicates $\varepsilon_{t}=A \cdot u_{t}$.

We take an impulse response analysis to track the evolution of the trade balance following an exchange rate shock, that is, real currency depreciation. The standard impulse response function is the dynamic response of an endogenous variable to a shock to the VAR system, which only works for linear models. Impulse response is to generate a moving average representation of the VAR, which is computed either by using the estimated ECM or directly from the unrestricted VAR. In our four dimensional structural analysis, the shocks correspond respectively to $X, Y, V, T B$ shocks when the structural disturbances 
are identified as exchange rate, GDP, volatility, and trade balance. This four variate system may require some restrictions on the impact of A matrix which dictate the shape of the impulse response functions as Ronayne (2011) says.

Just before going to the testing results, we discuss some data descriptions. This analysis includes four cyclical periods such as the first cycle of the Asian foreign exchange crisis (1996, 1Q-1999, 1Q), the second cycle of the IT bubble collapse (1999, 2Q-2003, 2Q), the third cycle of the financial crisis (2003, 3Q-2009, 2Q), and the fourth cycle of the Southern European fiscal crisis (2009, 3Q-2014, 1Q). The sample data set contains 73 individual quarterly periods in sixteen OECD nations plus China and India. The source of data is the Economic Research Economic Data of the Federal Reserve Bank of St. Louis, USA (FRED).

\section{Testing Results}

This section reports econometric procedures and summarizes our empirical findings. For the estimation of the behavioural dynamics of variables, a stationary set of time series in the VAR setting allows Dickey-Fuller stationarity tests, Johansen co-integration tests, Granger causality tests, deviations of impulse response functions.

In the stationarity-testing stage, we carry out unit root tests to check out the longrun equilibrium relation. The results by using the Augmented Dickey-Fuller tests of Dickey and Fuller (1979) with the lag length $k=0 \sim 2$ as suggested by the Akaike information criterion, are presented in Table 1 . They suggest that most of single variables are found to be non-stationary and first-difference stationary.

In the long-run equilibrium-testing state, we use the series integrated of order one and carry out the co-integration procedure of Engle and Granger (1987), Johansen (1991), and Johansen and Juselius (1990). The results in Table 2 present that for most countries, the null hypothesis of no cointegration is rejected at the $5 \%$ level, indicating at least one cointegrating vector in each case. We will use the cointegration relationship to analyse the behaviour of the trade balance and the output in both the short term and the long term.

We estimate the cointegration equation when the variables do cointegrate and the first-differenced equation as they do not cointegrate. By the way, the real effective exchange rate, its volatility calculated by the standard deviation, and real GDP could significantly explain the variation in the real trade balance in Table 2 . The positive sign of the coefficient of the real exchange rate suggests that the Marshall-Lerner condition is satisfied and thus the devaluation can improve the trade balance in the long run.

The results in Table 3 indicate the elasticity effects of the real exchange rate on the trade balance in the form of real exports divided by real imports in the long-run. Overall, the domestic currency devaluation improves the trade balance in the Netherlands, Korea and China while Mexico and Israel appear to be the opposite. The exchange rate volatility worsens the trade balance in the UK, Korea, Mexico, and India while Australia, the Netherlands, and China appear to be contrary. The long-run effects in the leading small open economy represent that real currency depreciation leads to improvement of trade balance in the Netherlands and Korea with an exception of Mexico and Israel while the exchange rate volatility worsens the trade balance in Korea, Mexico, and India with an exception of Australia and the Netherlands. 
Table 1 | Results of ADF Tests for Unit Roots

\begin{tabular}{|l|c|c|c|c|c|c|}
\hline \multirow{2}{*}{} & \multicolumn{3}{|c|}{ Level Variables } & \multicolumn{3}{c|}{ First Difference Variables } \\
\cline { 2 - 7 } & $\mathbf{X}$ & $\mathbf{Y}$ & $\mathbf{T B}$ & $\mathbf{X}$ & $\mathbf{Y}$ & TB \\
\hline US & -1.5 & -1.48 & -1.34 & $-6.15^{*}$ & $-3,22$ & $-7.89^{*}$ \\
\hline Switzerland & -0.73 & 0.14 & 0.24 & $-3.96^{*}$ & $-9.50^{*}$ & $-8.35^{*}$ \\
\hline Australia & -1.79 & 0.48 & -1.57 & $-7.74^{*}$ & $-5.21^{*}$ & $-8.28^{*}$ \\
\hline Canada & -1.22 & -2.68 & -2.94 & $-6.89^{*}$ & $-5.97^{*}$ & $-6.75^{*}$ \\
\hline United Kingdom & -1.21 & -1.95 & -1.58 & $-5.96^{*}$ & $-7.63^{*}$ & $-6.69^{*}$ \\
\hline Germany & -2.64 & -1.75 & -1.6 & $-5.59^{*}$ & $-2,57$ & $-8.14^{*}$ \\
\hline France & -2.38 & -1.69 & -0.82 & $-6.28^{*}$ & $-7.76^{*}$ & $-10.6^{*}$ \\
\hline Belgium & -1.58 & 0.14 & -1.25 & $-6.59^{*}$ & $-6.56^{*}$ & $-10.4^{*}$ \\
\hline Italy & -1.8 & 1.18 & -3.43 & $-6.98^{*}$ & $-4.54^{*}$ & $-8.68^{*}$ \\
\hline Netherlands & -1.9 & 1.14 & -2.56 & $-6.71^{*}$ & $-3,2$ & $-8.74^{*}$ \\
\hline Spain & -1.07 & -0.31 & -1.28 & $-4.96^{*}$ & $-3,47$ & $-7.72^{*}$ \\
\hline South Korea & -2.65 & -2.86 & $-4.08^{*}$ & $-3.76^{*}$ & $-6.68^{*}$ & $-7.92^{*}$ \\
\hline Mexico & -2.81 & $-4.50^{*}$ & $-3.87^{*}$ & $-7.74^{*}$ & $-3.29^{*}$ & $-8.60^{*}$ \\
\hline Chile & -2.16 & 0 & -1.45 & $-6.93^{*}$ & $-4.82^{*}$ & $-7.35^{*}$ \\
\hline Israel & -1.58 & -0.37 & -2.97 & $-7.67^{*}$ & $-7.78^{*}$ & $-10.63^{*}$ \\
\hline China & -0.3 & $-5.15^{*}$ & $-4.25^{*}$ & $-6.08^{*}$ & $-130.0^{*}$ & $-9.18^{*}$ \\
\hline India & -3.11 & -1.21 & -2.36 & $-8.52^{*}$ & $-10.23^{*}$ & $-8.08^{*}$ \\
\hline
\end{tabular}

Note: *Significant at the $1 \%$ level (critical value $=-3.52$ ) for the real variables between $1996,1 \mathrm{Q} \sim 2014,1 \mathrm{Q}$ in the model with intercept.

First, the change in the real trade balance can improve about $0.19 \%$ on average in response to $1 \%$ real depreciation, while a $1 \%$ rise in real exchange rate volatility leads to about $0.01 \%$ deterioration in the real trade balance in Korea. Second, a $1 \%$ rise in real exchange rate volatility leads to $0.02 \%$ improvement in the real trade balance in Australia but to $0.01 \%$ deterioration in the real trade balance in the UK. Third, the change in the real trade balance can improve about $0.4 \%$ in response to $1 \%$ real depreciation, while a $1 \%$ rise in real exchange rate volatility leads to about $0.004 \%$ improvement in the real trade balance in the Netherlands. Forth, the change in the real trade balance can deteriorate about $0.09 \%$ in response to $1 \%$ real depreciation, while a $1 \%$ rise in real exchange rate volatility leads to about $0.0004 \%$ deterioration in the real trade balance in Mexico. Fifth, the change in the real trade balance can deteriorate about $0.26 \%$ in response to $1 \%$ real depreciation in Israel while a $1 \%$ rise in real exchange rate volatility leads to $0.02 \%$ deterioration in the real trade balance in India. Finally, the change rate in the trade balance can improve 1.05 on average in response to a unit change rate of the exchange rate, while a unit change rate in its volatility leads to 1.40 improvement of the change rate in the trade balance in China. 
Table 2 | Results of Engle-Granger Tests for Cointegration

\begin{tabular}{|c|c|c|c|c|c|c|}
\hline \multirow{3}{*}{\begin{tabular}{|l} 
\\
US
\end{tabular}} & \multirow{3}{*}{$\begin{array}{c}\begin{array}{c}\text { Null } \\
\text { Statistic }\end{array} \\
-5.15^{*}\end{array}$} & \multicolumn{5}{|c|}{ Cointegration Equation } \\
\hline & & \multicolumn{5}{|c|}{ TB $=$ Constant + Trend $+X+Y+V$} \\
\hline & & $70.1(0.00)$ & $-0.001(0.00)$ & $0.23(0.15)$ & $-2.77(0.00)$ & $0.009(0.16)$ \\
\hline Japan & $-2,36$ & $23.3(0.14)$ & $-0.003(0.01)$ & $0.06(0.59)$ & $-0.84(0.15)$ & $-0.001(0.85)$ \\
\hline Switzerland & $-6.72^{*}$ & $12.1(0.01)$ & $0.002(0.00)$ & $0.09(0.13)$ & $-0.59(0.01)$ & $-0.004(0.12)$ \\
\hline Australia & $-4.57 \wedge$ & $39.6(0.00)$ & $0.005(0.00)$ & $-0.04(0.65)$ & $-1.86(0.00)$ & $0.02(0.00)$ \\
\hline Canada & $-2,94$ & $21.6(0.05)$ & $-0.004(0.00)$ & $-0.08(0.44)$ & $1.01(0.04)$ & $-0.01(0.16)$ \\
\hline United Kingdom & $-7.58^{*}$ & $10.4(0.00)$ & $-0.003(0.00)$ & $0.03(0.45)$ & $-0.48(0.00)$ & $-0.01(0.00)$ \\
\hline Germany & $-3,87$ & $-20.9(0.00)$ & $0.002(0.00)$ & $0.56(0.00)$ & $0.95(0.00)$ & $-0.004(0.37)$ \\
\hline France & $-3,51$ & $4.77(0.05)$ & $-0.003(0.00)$ & $-0.14(0.16)$ & $-0.21(0.06)$ & $-0.008(0.08)$ \\
\hline Belgium & $-5.12^{*}$ & $-4.23(0.24)$ & $-0.001(0.00)$ & $-0.04(0.64)$ & $0.21(0.23)$ & $-0.004(0.15)$ \\
\hline Italy & $-7.15^{*}$ & $40.0(0.00)$ & $-0.01(0.00)$ & $0.17(0.26)$ & $-1.82(0.00)$ & $0.002(0.69)$ \\
\hline Netherlands & $-6.65^{*}$ & $2.68(0.01)$ & $-0.0002(0.09)$ & $0.40(0.00)$ & $-0.12(0.01)$ & $0.004(0.01)$ \\
\hline Spain & $-5.22^{*}$ & $31.9(0.00)$ & $-0.001(0.00)$ & $-0.40(0.00)$ & $-1.51(0.00)$ & $-0.007(0.18)$ \\
\hline South Korea & $-4.38^{\wedge}$ & $51.5(0.00)$ & $0.001(0.01)$ & $0.19(0.08)$ & $-1.84(0.00)$ & $-0.01(0.04)$ \\
\hline Mexico & $-5.78^{*}$ & $-5.57(0.00)$ & $0.001(0.00)$ & $-0.09(0.05)$ & $0.23(0.00)$ & $-0.0004(0.9)$ \\
\hline Chile & $-4,16$ & $-22.1(0.00)$ & $-0.01(0.00)$ & $0.78(0.11)$ & $0.90(0.19)$ & $-0.04(0.01)$ \\
\hline Israel & $-5.17^{*}$ & $-5.12(0.34)$ & $-0.0002(0.80)$ & $-0.26(0.00)$ & $0.23(0.36)$ & $-0.005(0.48)$ \\
\hline China & $-2,07$ & $-0.30(0.06)$ & $0.005(0.08)$ & $-0.12(0.70)$ & $0.06(0.01)$ & $0.01(0.34)$ \\
\hline India & $-5.35^{*}$ & $10.7(0.26)$ & $-0.003(0.02)$ & $-0.36(0.36)$ & $-0.43(0.26)$ & $-0.02(0.04)$ \\
\hline
\end{tabular}

Note: *Significant at the $5 \%$ level (^significant at $10 \%)$ with the null of no cointegration for the cointegrating vectors of the logarithmic real variables. The values in parentheses are $p$-values for explanatory variables, respectively.

We examine the short-run effect of the exchange rate on the trade balance by using VECM which represents the dynamics of the trade balance equation and the output in the short term in Table 4. We assume that VECM is adequately specified with the maximum five lags and diagnostic tests of residual-normality and no-autocorrelation.

Table 4.1 indicates the statistically significant VECM results for the trade balance. The real effective exchange rate and its volatility are important determinants of the real 
Table 3 | Summary of Long-run Exchange Rate Effects on the Trade Balance

\begin{tabular}{|l|c|c|c|c|}
\hline & \multicolumn{2}{|c|}{ Cointegration Equation } & \multicolumn{2}{c|}{ First-Difference Equation } \\
\hline & $\mathbf{X}$ & $\mathbf{V}$ & $\mathbf{X}$ & $\mathbf{V}$ \\
\hline US & $0.23(0.15)$ & $0.009(0.16)$ & - & - \\
\hline Japan & - & - & $-0.08(0.51)$ & $-0.08(0.55)$ \\
\hline Switzerland & $0.09(0.13)$ & $-0.004(0.12)$ & - & - \\
\hline Australia & $-0.04(0.65)$ & $0.02(0.00)^{*}$ & - & - \\
\hline Canada & - & - & $-0.12(0.50)$ & $0.26(0.13)$ \\
\hline United Kingdom & $0.03(0.45)$ & $-0.01(0.00)^{*}$ & - & - \\
\hline Germany & - & - & $0.34(0.23)$ & $-0.16(0.58)$ \\
\hline France & - & - & $0.22(0.26)$ & $-0.22(0.32)$ \\
\hline Belgium & $-0.04(0.64)$ & $-0.004(0.15)$ & - & - \\
\hline Italy & $0.17(0.26)$ & $0.002(0.69)$ & - & - \\
\hline Netherlands & $0.40(0.00)^{*}$ & $0.004(0.01)^{*}$ & - & - \\
\hline Spain & $-0.40(0.00)^{*}$ & $-0.007(0.18)$ & - & - \\
\hline South Korea & $0.19(0.08)^{\wedge}$ & $-0.01(0.04)^{*}$ & - & - \\
\hline Mexico & $-0.09(0.05)^{*}$ & $-0.0004(0.9) \wedge$ & - & - \\
\hline Chile & - & - & - & - \\
\hline Israel & $-0.26(0.00)^{*}$ & $-0.005(0.48)$ & $-05(0.02)^{*}$ & - \\
\hline China & - & $-0.02(0.04)^{*}$ & - & - \\
\hline India & - & - & - & - \\
\hline
\end{tabular}

Note: The cointegration equation and the first-difference equation respectively represents the estimated coefficient of the real effective exchange rate and its volatility on the real trade balance when our regression model is tested by using each of the level-cointegrated logarithmic variables and first-difference stationary variables between 1996, 1Q 2014, 1Q. And the values in the parentheses are $p$-values for explanatory variables respectively. ${ }^{*}$ Significant at the $5 \%$ level (significant at $10 \%$ ).

trade balance in the short run. The short-run effects in the leading small open economy represent that real currency depreciation leads to an immediate improvement of trade balance in Switzerland, Australia, and India, while currency depreciation immediately worsens the trade balance in the Netherland, Spain, and Korea. Also, currency volatility immediately worsens the trade balance in Belgium and Spain, while volatility immediately improves the trade balance in the Australia, Italy, the Netherlands, Korea, and Israel 
Table 4.1 | Summary of Short-Run Exchange Rate Effects on the Trade Balance

\begin{tabular}{|c|c|c|c|c|c|c|}
\hline & \multicolumn{6}{|c|}{ Coefficients of Estimates of (Dependent Variable: $\Delta T B$ ) } \\
\hline & Constant & ECT & $\Delta \mathbf{x}$ & $\Delta \mathbf{V}$ & $\Delta \mathbf{Y}$ & $\Delta \mathrm{TB}$ \\
\hline \multirow{3}{*}{ US } & $0.04(0.09)^{\wedge}$ & $-0.07(0.09)^{\wedge}$ & $0.25(0.00)^{*} 4 \mathrm{~L}$ & $-0.38(0.00) * 2 \mathrm{~L}$ & - & $-1.04(0.00)^{*} 1 \mathrm{~L}$ \\
\hline & - & - & - & - & - & $-1.18(0.00) * 2 \mathrm{~L}$ \\
\hline & - & - & - & - & - & $-0.98(0.00) * 3 \mathrm{~L}$ \\
\hline \multirow{4}{*}{ Switzerland } & $0.06(0.72)$ & $-0.05(0.71)$ & $0.42(0.09) \wedge 2 \mathrm{~L}$ & - & - & $-1.34(0.00)^{*} 1 \mathrm{~L}$ \\
\hline & - & - & - & - & - & $-1.27(0.00) * 2 \mathrm{~L}$ \\
\hline & - & - & - & - & - & $-1.04(0.00) * 3 \mathrm{~L}$ \\
\hline & - & - & - & - & - & $-0.52(0.02) * 4 \mathrm{~L}$ \\
\hline \multirow{4}{*}{ Australia } & $-0.03(0.75)$ & $0.04(0.74)$ & $0.65(0.00) * 2 \mathrm{~L}$ & $0.36(0.09)^{\wedge} 1 \mathrm{~L}$ & $-1.7 \mathrm{e}(0.00)^{*} 1 \mathrm{~L}$ & $-0.77(0.00)^{*} 1 \mathrm{~L}$ \\
\hline & - & - & $0.52(0.07) \wedge 3 \mathrm{~L}$ & - & - & $-0.52(0.00) * 2 \mathrm{~L}$ \\
\hline & - & - & $0.84(0.00) * 4 \mathrm{~L}$ & - & - & $-0.48(0.00) * 3 \mathrm{~L}$ \\
\hline & - & - & $0.65(0.00) * 5 \mathrm{~L}$ & - & - & - \\
\hline \multirow{4}{*}{$\begin{array}{l}\text { United } \\
\text { Kingdom }\end{array}$} & $0.01(0.81)$ & $-0.01(0.81)$ & - & - & $-0.29(0.08) \wedge 2 \mathrm{~L}$ & $-1.25(0.00)^{*} 1 \mathrm{~L}$ \\
\hline & - & - & - & - & - & $-1.27(0.00) * 2 \mathrm{~L}$ \\
\hline & - & - & - & - & - & $-1.04(0.00) * 3 \mathrm{~L}$ \\
\hline & - & - & - & - & - & $-0.44(0.07)^{\wedge} 4 \mathrm{~L}$ \\
\hline \multirow{3}{*}{ Belgium } & $0.07(0.36)$ & $-0.07(0.00)^{*}$ & - & $-0.62(0.04) * 3 \mathrm{~L}$ & - & $-0.93(0.00)^{*} 1 \mathrm{~L}$ \\
\hline & - & - & - & $-0.59(0.03) * 4 \mathrm{~L}$ & - & $-1.01(0.00)^{*} 2 \mathrm{~L}$ \\
\hline & - & - & - & - & - & $-0.59(0.02) * 3 \mathrm{~L}$ \\
\hline \multirow{3}{*}{ Italy } & $-0.04(0.54)$ & $0.04(0.52)$ & - & $0.51(0.1) * 1 \mathrm{~L}$ & $-0.5 \mathrm{e}(0.06)^{\wedge} \wedge \mathrm{L}$ & $-0.9(0.00) * 1 \mathrm{~L}$ \\
\hline & - & - & - & $0.71(0.04) * 2 \mathrm{~L}$ & - & $-0.89(0.00) * 2 \mathrm{~L}$ \\
\hline & - & - & - & - & - & $-0.88(0.00) * 3 \mathrm{~L}$ \\
\hline \multirow{3}{*}{$\begin{array}{l}\text { Nether- } \\
\text { lands }\end{array}$} & $0.09(0.57)$ & $-0.08(0.57)$ & $-0.31(0.11) \wedge 5 \mathrm{~L}$ & $0.31(0.11)^{\wedge} 1 \mathrm{~L}$ & - & $-1.20(0.00)^{*} 1 \mathrm{~L}$ \\
\hline & - & - & - & - & - & $-1.04(0.00) * 2 \mathrm{~L}$ \\
\hline & - & - & - & - & - & $-0.95(0.00) * 3 \mathrm{~L}$ \\
\hline \multirow{4}{*}{ Spain } & $0.008(0.79)$ & $-0.01(0.78)$ & $-0.88(0.02) * 2 \mathrm{~L}$ & \begin{tabular}{|l|}
$-0.46(0.09) \wedge 5 \mathrm{~L}$ \\
\end{tabular} & - & $-1.11(0.00)^{*} 1 \mathrm{~L}$ \\
\hline & - & - & $-1.08(0.00) * 3 \mathrm{~L}$ & - & - & $-1.18(0.00) * 2 \mathrm{~L}$ \\
\hline & - & - & $-0.90(0.00)^{*} 4 \mathrm{~L}$ & - & - & $-0.93(0.00) * 3 \mathrm{~L}$ \\
\hline & - & - & - & - & - & $-0.41(0.03) * 4 \mathrm{~L}$ \\
\hline \multirow{3}{*}{$\begin{array}{l}\text { South } \\
\text { Korea }\end{array}$} & $0.28(0.01)^{*}$ & $-0.25(0.01)^{*}$ & $-0.47(0.07)^{\wedge} 1 \mathrm{~L}$ & $0.71(0.01) * 2 \mathrm{~L}$ & - & $-1.25(0.00)^{*} 1 \mathrm{~L}$ \\
\hline & - & - & - & $0.94(0.00)^{*} 3 \mathrm{~L}$ & - & $-0.94(0.00) * 2 \mathrm{~L}$ \\
\hline & - & - & - & $0.62(0.06) \wedge 4 \mathrm{~L}$ & - & $-0.64(0.00) * 3 \mathrm{~L}$ \\
\hline \multirow{3}{*}{ Mexico } & $-0.36(0.12)$ & $0.37(0.12)$ & - & - & - & $-1.13(0.00)^{*} 1 \mathrm{~L}$ \\
\hline & - & - & - & - & - & $-1.23(0.00) * 2 \mathrm{~L}$ \\
\hline & - & - & - & - & - & $-1.06(0.00) * 3 \mathrm{~L}$ \\
\hline \multirow{4}{*}{ Israel } & $-0.01(0.95)$ & $0.01(0.95)$ & - & $0.57(0.05) * 2 \mathrm{~L}$ & - & $-1.17(0.00)^{*} 1 \mathrm{~L}$ \\
\hline & - & - & - & - & - & $-1.40(0.00) * 2 \mathrm{~L}$ \\
\hline & - & - & - & - & - & $-0.77(0.01) * 3 \mathrm{~L}$ \\
\hline & - & - & - & - & - & $-0.43(0.07)^{\wedge} 4 \mathrm{~L}$ \\
\hline \multirow{4}{*}{ India } & $-0.12(0.55)$ & $0.15(0.55)$ & $1.67(0.05) * 4 \mathrm{~L}$ & - & - & $-1.21(0.00)^{*} 1 \mathrm{~L}$ \\
\hline & - & - & - & - & - & $-1.12(0.00)^{*} 2 \mathrm{~L}$ \\
\hline & - & - & - & - & - & $-1.05(0.00) * 3 \mathrm{~L}$ \\
\hline & - & - & - & - & - & $-0.54(0.01) * 4 \mathrm{~L}$ \\
\hline
\end{tabular}

Note: Our VECM model is tested by using each of the level-cointegrated variables for all the periods between 1996, 1Q 2014, 1Q. The table represents statistically significant results at the $10 \%$ level except both constant and ECT. L represents the time-lags. Here the values in the parentheses are $p$-values for explanatory variables respectively. ${ }^{*}$ Significant at the $5 \%$ level (significant at $10 \%$ ). 
Table 4.2. | Summary of Short-Run Exchange Rate Effects on the Output

\begin{tabular}{|c|c|c|c|c|c|c|}
\hline & \multicolumn{6}{|c|}{ Coefficients of Estimates of (Dependent Variable: $\Delta T B$ ) } \\
\hline & Constant & ECT & $\Delta \mathbf{x}$ & $\Delta \mathbf{V}$ & $\Delta \mathbf{Y}$ & $\Delta T B$ \\
\hline \multirow{3}{*}{ US } & $-2.84 \mathrm{e}(0.02)$ & $4.45 \mathrm{e}(0.02)$ & - & $-1.5 e(0.00) 3 L$ & $-0.81(0.00) 1 \mathrm{~L}$ & $-1.5 e(0.08) 2 \mathrm{~L}$ \\
\hline & - & - & - & - & $-0.98(0.00) 2 \mathrm{~L}$ & $-1.6(0.06) 3 \mathrm{~L}$ \\
\hline & - & - & - & - & $-0.48(0.02) 3 \mathrm{~L}$ & - \\
\hline \multirow{3}{*}{$\begin{array}{l}\text { Switzer- } \\
\text { land }\end{array}$} & $0.12 \mathrm{e}(0.64)$ & $-0.12(0.65)$ & - & - & $-0.81(0.00) 1 \mathrm{~L}$ & - \\
\hline & - & - & - & - & $-0.53(0.00) 2 \mathrm{~L}$ & - \\
\hline & - & - & - & - & $-0.68(0.00) 3 \mathrm{~L}$ & - \\
\hline \multirow{3}{*}{ Australia } & $0.12 \mathrm{e}(0.76)$ & $-0.14(0.73)$ & - & - & $-0.63(0.00) 1 \mathrm{~L}$ & - \\
\hline & - & - & - & - & $-0.40(0.00) 2 \mathrm{~L}$ & - \\
\hline & - & - & - & - & $-0.32(0.08) 3 \mathrm{~L}$ & - \\
\hline \multirow{5}{*}{$\begin{array}{l}\text { United } \\
\text { Kingdom }\end{array}$} & $-0.58 \mathrm{e}(0.14)$ & $0.74 \mathrm{e}(0.14)$ & $0.34(0.00) 2 \mathrm{~L}$ & - & $-0.70(0.00) 1 \mathrm{~L}$ & - \\
\hline & - & - & - & - & $-0.36(0.04) 2 \mathrm{~L}$ & - \\
\hline & - & - & - & - & $-0.53(0.00) 3 \mathrm{~L}$ & - \\
\hline & - & - & - & - & $-0.40(0.04) 4 \mathrm{~L}$ & - \\
\hline & - & - & - & - & $-0.33(0.02) 5 \mathrm{~L}$ & - \\
\hline \multirow{3}{*}{ Belgium } & $0.1 \mathrm{e}(0.28)$ & $-0.1 e(0.28)$ & - & - & $-0.45(0.00) 1 \mathrm{~L}$ & $0.62 \mathrm{e}(0.01) 2 \mathrm{~L}$ \\
\hline & - & - & - & - & $-0.33(0.04) 2 \mathrm{~L}$ & $0.51(0.09) 3 \mathrm{~L}$ \\
\hline & - & - & - & - & $-0.29(0.07) 3 L$ & $0.4 \mathrm{e}(0.05) 5 \mathrm{~L}$ \\
\hline Italy & $0.56 \mathrm{e}(0.13)$ & $-0.53 e(0.13)$ & - & - & $-0.29(0.04) 1 \mathrm{~L}$ & - \\
\hline \multirow{3}{*}{$\begin{array}{l}\text { Nether- } \\
\text { lands }\end{array}$} & $-0.9 e(0.10)$ & $0.8 \mathrm{e}(0.10)$ & $0.14 \mathrm{e}(0.08) 1 \mathrm{~L}$ & - & $-0.88(0.00) 1 \mathrm{~L}$ & - \\
\hline & - & - & - & - & $-0.71(0.00) 2 \mathrm{~L}$ & - \\
\hline & - & - & - & - & $-0.49(0.02) 3 \mathrm{~L}$ & - \\
\hline \multirow{2}{*}{ Spain } & $-0.4 e(0.04)$ & $0.5 \mathrm{e}(0.04)$ & - & - & $-0.7(0.00) 1 \mathrm{~L}$ & $0.31 \mathrm{e}(0.01) 4 \mathrm{~L}$ \\
\hline & - & - & - & - & $-0.33(0.03) 2 \mathrm{~L}$ & - \\
\hline \multirow{3}{*}{$\begin{array}{l}\text { South } \\
\text { Korea }\end{array}$} & -0.17 e $(0.00)$ & $0.15 \mathrm{e}(0.00)$ & $0.48 \mathrm{e}(0.00) 1 \mathrm{~L}$ & - & $-0.50(0.02) 1 \mathrm{~L}$ & - \\
\hline & - & - & $2.71 \mathrm{e}(0.08) 3 \mathrm{~L}$ & - & $-0.43(0.05) 2 \mathrm{~L}$ & - \\
\hline & - & - & - & - & $-0.43(0.01) 5 \mathrm{~L}$ & - \\
\hline \multirow{2}{*}{ Mexico } & $-0.15 e(0.54)$ & $0.16 \mathrm{e}(0.54)$ & $0.26 \mathrm{e}(0.00) 1 \mathrm{~L}$ & - & $-0.46(0.00) 1 \mathrm{~L}$ & $0.53 e(0.00) 1 \mathrm{~L}$ \\
\hline & - & - & $0.22 \mathrm{e}(0.00) 2 \mathrm{~L}$ & - & - & $0.53 e(0.04) 2 \mathrm{~L}$ \\
\hline \multirow{3}{*}{ Israel } & 0.33 e $(0.73)$ & $-0.36 \mathrm{e}(0.73)$ & - & - & $-0.73(0.00) 1 \mathrm{~L}$ & $0.21 \mathrm{e}(0.10) 3 \mathrm{~L}$ \\
\hline & - & - & - & - & $-0.56(0.00) 2 \mathrm{~L}$ & $0.24 \mathrm{e}(0.02) 4 \mathrm{~L}$ \\
\hline & - & - & - & - & $-0.33(0.10) 3 \mathrm{~L}$ & - \\
\hline \multirow{4}{*}{ India } & $-6.72 e(0.46)$ & $0.86 \mathrm{e}(0.46)$ & - & - & $-0.97(0.00) 1 \mathrm{~L}$ & - \\
\hline & - & - & - & - & $-1.22(0.00) 2 \mathrm{~L}$ & - \\
\hline & - & - & - & - & $-0.85(0.00) 3 \mathrm{~L}$ & - \\
\hline & - & - & - & - & $-0.49(0.04) 4 \mathrm{~L}$ & - \\
\hline
\end{tabular}

Note: Our VECM model is tested by using each of the level-cointegrated variables for all the periods between 1996, 1Q 2014, 1Q. The table represents statistically significant results at the $10 \%$ level except both constant and ECT. L represents the time-lags. The values in the parentheses are $p$-values for explanatory variables respectively. Here e means e+011 etc. as a measure unit. 
Table 5.1 | Summary of Short-Run Exchange Rate Effects on the Trade Balance

\begin{tabular}{|c|c|c|c|c|c|}
\hline & \multicolumn{5}{|c|}{ Coefficients of Estimates of (Dependent Variable: $\Delta T B$ ) } \\
\hline & Constant & $\Delta \mathbf{x}$ & $\Delta \mathbf{V}$ & $\Delta \mathbf{Y}$ & $\Delta \mathrm{TB}$ \\
\hline \multirow{3}{*}{ Japan } & $-1.76 \mathrm{e}(0.76)$ & - & $-0.36(0.01) 2 \mathrm{~L}$ & $-0.15 \mathrm{e}(0.03) 2 \mathrm{~L}$ & - \\
\hline & - & - & $0.25(0.08) 3 \mathrm{~L}$ & $-0.14 \mathrm{e}(0.05) 4 \mathrm{~L}$ & - \\
\hline & - & - & $-0.36(0.03) 4 \mathrm{~L}$ & - & - \\
\hline \multirow{2}{*}{ Canada } & $-0.73 e(0.22)$ & - & $0.42(0.02) 3 \mathrm{~L}$ & $0.77 \mathrm{e}(0.02) 3 \mathrm{~L}$ & $-0.27(0.03) 3 L$ \\
\hline & - & - & $-0.47(0.01) 4 \mathrm{~L}$ & - & - \\
\hline Germany & 0.15 e (0.73) & $0.61(0.06) 1 \mathrm{~L}$ & - & - & - \\
\hline \multirow{2}{*}{ France } & $-0.43 e(0.10)$ & - & - & $-0.25 e(0.08) 2 \mathrm{~L}$ & $-0.24(0.10) 1 \mathrm{~L}$ \\
\hline & - & - & - & $-0.26 \mathrm{e}(0.05) 4 \mathrm{~L}$ & - \\
\hline \multirow{3}{*}{ Chile } & $-0.03(0.15)$ & $2.25(0.00) 5 \mathrm{~L}$ & $-1.83(0.02) 3 \mathrm{~L}$ & - & $-0.44(0.01) 2 L$ \\
\hline & - & - & - & - & $-0.48(0.01) 3 L$ \\
\hline & - & - & - & - & $-0.63(0.00) 5 L$ \\
\hline China & $0.11(0.34)$ & - & - & - & - \\
\hline
\end{tabular}

Note: Our VAR model is tested by using each of the first stationary variables for all the periods between 1996, 1Q 2014, 1Q. The table represents statistically significant results at the $10 \%$ level except constant. $\mathrm{L}$ represents the time-lags. The values in parentheses are $p$-values for explanatory variables respectively. Here e means e+011 etc. as a measure unit.

In the case of the largest economy, the real depreciation leads to an immediate improvement of trade balance but currency depreciation immediately worsens the trade balance in the US. The real exchange rate change is significant in the fourth quarter, while its volatility change is significant in the second quarter.

In addition, the short-run adjustment of each variable toward the long-run equilibrium is rather stable in the US, Belgium, and Korea. The self-lagged terms of trade balance are significant and their recent effects are more influential in the most countries.

Table 4.2 indicates the statistically significant VECM results for the GDP. The real effective exchange rate may be an important determinant of the real output in the short run. The coefficients of the exchange rate suggest that currency depreciation immediately increases the GDP in the UK, the Netherlands, Korea, and Mexico.

Now, we use the VAR model to estimate the no cointegrated short-run equation by using first difference variables. Table 5.1 and 5.2 indicate the statistically significant VAR results for the trade balance and the GDP, respectively.

Table 5.1 indicates the statistically significant VAR results for the trade balance. The real effective exchange rate and its volatility may be important determinants in the short run. The coefficients of the exchange rate suggest that currency depreciation improves the trade balance in Germany and Chile. The coefficients of volatility suggest that volatility mostly decreases the trade balance in Japan, Canada, and Chile. 
Table 5.2 | Summary of Short-Run Exchange Rate Effects on the Output

\begin{tabular}{|l|c|c|c|c|c|}
\hline & \multicolumn{5}{|c|}{ Coefficients of Estimates of (Dependent Variable: $\Delta \mathrm{Y})$} \\
\hline \multirow{2}{*}{ Japan } & Constant & $\Delta \mathbf{X}$ & $\boldsymbol{\Delta V}$ & $\Delta \mathrm{Y}$ & $\Delta \mathrm{TB}$ \\
\hline Cananda & $0.21 \mathrm{e}(0.02)$ & - & $-0.56 \mathrm{e}(0.03) 4 \mathrm{~L}$ & - & $-0.30 \mathrm{e}(0.11) 4 \mathrm{~L}$ \\
\hline \multirow{2}{*}{ Germany } & $0.47 \mathrm{e}(0.08)$ & - & - & - & $-0.13 \mathrm{e}(0.03) 2 \mathrm{~L}$ \\
\cline { 2 - 7 } & $-0.38 \mathrm{e}(0.36)$ & $0.61 \mathrm{e}(0.04) 1 \mathrm{~L}$ & - & $-0.24(0.07) 1 \mathrm{~L}$ & $-0.32 \mathrm{e}(0.01) 1 \mathrm{~L}$ \\
\hline \multirow{2}{*}{ France } & - & $0.50 \mathrm{e}(0.09) 5 \mathrm{~L}$ & - & - & $-0.26 \mathrm{e}(0.04) 4 \mathrm{~L}$ \\
\hline \multirow{2}{*}{ Chile } & $0.13 \mathrm{e}(0.59)$ & $-0.40 \mathrm{e}(0.07) 2 \mathrm{~L}$ & - & $0.30(0.02) 4 \mathrm{~L}$ & - \\
\hline \multirow{3}{*}{ China } & $0.47 \mathrm{e}(0.40)$ & - & - & $0.52(0.07) 1 \mathrm{~L}$ & - \\
\cline { 2 - 7 } & $3.82(0.45)$ & $-0.41 \mathrm{e}(0.08) 5 \mathrm{~L}$ & $-0.15 \mathrm{e}(0.08) 1 \mathrm{~L}$ & $-1.93(0.06) 1 \mathrm{~L}$ & $61.3(0.05) 2 \mathrm{~L}$ \\
\cline { 2 - 7 } & - & - & $-0.32 \mathrm{e}(0.09) 2 \mathrm{~L}$ & $0.74(0.07) 4 \mathrm{~L}$ & - \\
\hline
\end{tabular}

Note: Our VAR model is tested by using each of the first stationary variables for all the periods between 1996, 1Q 2014, 1Q. The table represents statistically significant results at the $10 \%$ level except constant. $\mathrm{L}$ represents the time-lags. The values in the parentheses are $p$-values for explanatory variables respectively. Here e means e+011 etc. as a measure unit.

Table 5.2 indicates the statistically significant VAR results for the GDP. The real effective exchange rate and its volatility may be important determinants in the short run. The coefficients of the exchange rate suggest that currency depreciation increases the GDP in Germany while depreciation decreases the GDP in France and China. The coefficients of volatility suggest that volatility decreases the GDP in Japan and China.

We examine whether the real trade balance is an endogenous variable, while the real effective exchange rate, the real GDP, and the real effective exchange rate volatility are exogenous, respectively. In this case, the cointegrating vector can enter ECM for the trade balance. The Granger causality tests of Granger (1980) are carried out to examine the direction of the relationship among real trade balance, real GDP, real effective exchange rate, and its volatility in the VAR.

Table 6 indicates whether the lagged real effective exchange rate, its volatility, and lagged real output significantly affect the real trade balance, or whether the lagged real effective exchange rate, its volatility, and lagged real trade balance affect the real output when appropriate one to three lags are selected by AIC. The results of the trade balance and the output as an endogenous variable are marked in Table 6, indicating the direction of causation may not be only one direction. The trade balance seems to be more endogenous in the US, the Netherlands, and Israel while the GDP may be more endogenous in the UK, France, and Mexico. 
Table 6 | Results of Granger Tests for Causality

\begin{tabular}{|l|c|c|}
\hline \multirow{2}{*}{} & \multicolumn{2}{|c|}{ Causality Tests } \\
\cline { 2 - 3 } & TB $=\mathbf{f}(\mathbf{X}, \mathbf{Y}, \mathbf{V})$ & $\mathbf{Y}=\mathbf{f}(\mathrm{TB}, \mathbf{X}, \mathbf{V})$ \\
\hline US & $(0.01)(0.01)(0.23)$ & $(0.00)(0.22)(0.35)$ \\
\hline Japan & $(0.96)(0.37)(0.53)$ & $(0.22)(0.04)(0.76)$ \\
\hline Switzerland & $(0.30)(0.22)(0.91)$ & $(0.61)(0.18)(0.75)$ \\
\hline Australia & $(0.09)(0.26)(0.12)$ & $(0.33)(0.10)(0.33)$ \\
\hline Canada & $(0.07)(0.81)(0.89)$ & $(0.43)(0.44)(0.97)$ \\
\hline United Kingdom & $(0.37)(0.42)(0.97)$ & $(0.00)(0.00)(0.01)$ \\
\hline Germany & $(0.95)(0.00)(0.59)$ & $(0.03)(0.48)(0.47)$ \\
\hline France & $(0.51)(0.86)(0.70)$ & $(0.00)(0.35)(0.02)$ \\
\hline Belgium & $(0.17)(0.84)(0.83)$ & $(0.00)(0.41)(0.99)$ \\
\hline Italy & $(0.53)(0.12)(0.17)$ & $(0.00)(0.31)(0.04)$ \\
\hline Netherlands & $(0.00)(0.00)(0.55)$ & $(0.11)(0.67)(0.49)$ \\
\hline Spain & $(0.51)(0.67)(0.96)$ & $(0.97)(0.02)(0.94)$ \\
\hline South Korea & $(0.51)(0.01)(0.98)$ & $(0.27)(0.01)(0.16)$ \\
\hline Mexico & $(0.00)(0.85)(0.12)$ & $(0.00)(0.00)(0.00)$ \\
\hline Chile & $(0.05)(0.90)(0.27)$ & $(0.55)(0.15)(0.94)$ \\
\hline Israel & $(0.07)(0.00)(0.36)$ & $(0.61)(0.56)(0.78)$ \\
\hline China & $(0.40)(0.69)(0.11)$ & $(0.37)(0.69)(0.04)$ \\
\hline India & $(0.35)(0.02)(0.74)$ & $(0.78)(0.31)(0.97)$ \\
\hline
\end{tabular}

Note: The values in parentheses are $p$-values for the logarithmic explanatory real variables respectively in each model between 1996, 1Q 2014, 1Q.

We perform the procedure for graphing impulse responses in order to examine the dynamic effect of the exchange rate on the trade balance. This organizes the graphs of an impulse response functions from an estimated VECM or VAR, which are computed by using the covariance matrix with the model or a Choleski factorization of that matrix. Here, we calculate twelve steps of the impulse responses to all the orthogonalized shocks to the equations. 
Response of USA Trade Balance to Exchange Rate Shock

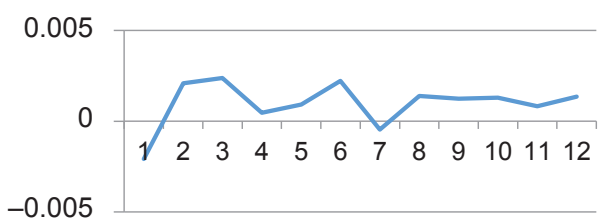

Response of JapanTrade Balance to Exchange Rate Shock

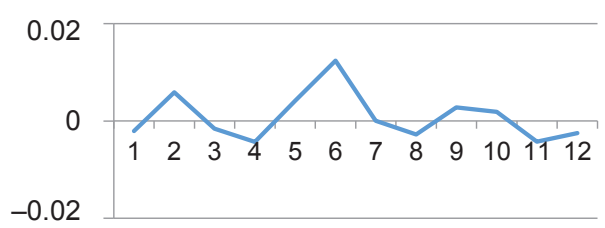

Response of Swiss Trade Balance to Exchange Rate Shock

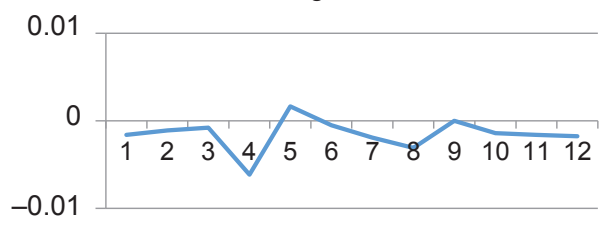

Response of Australia Trade Balance to Exchange Rate Shock

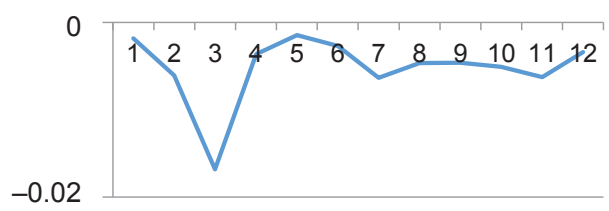

Response of Canada Trade Balance to Exchange Rate Shock

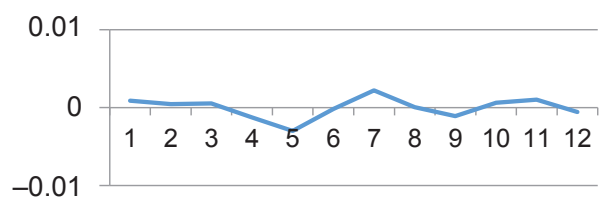

Response of USA Trade Balance to Volatility Shock

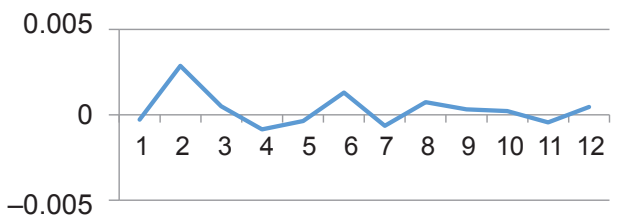

Response of Japan Trade Balance to Volatility Shock

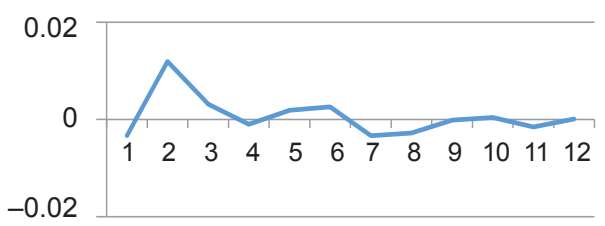

Response of Swiss Trade Balance to Volatility Shock

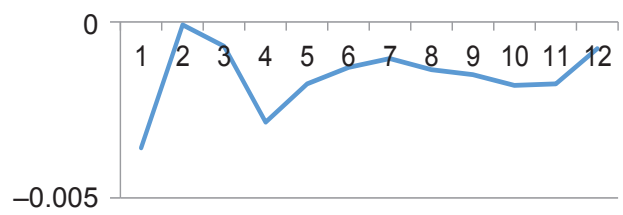

Response of Australia Trade Balance to Volatility Shock

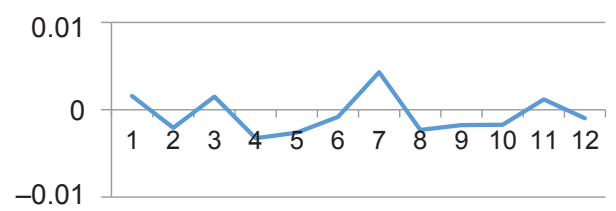

Response of Canada Trade Balance to Volatility Shock

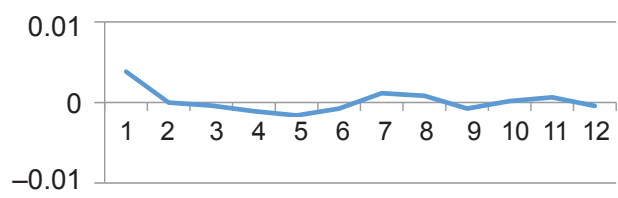


Response of UK Trade Balance

to Exchange Rate Shock

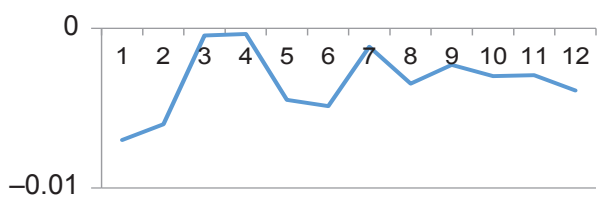

Response of GermanyTrade Balance

to Exchange Rate Shock

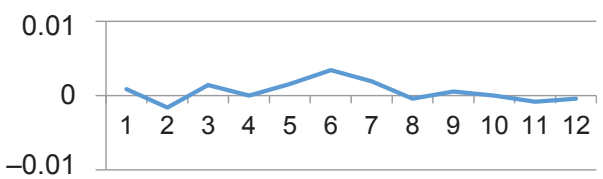

Response of France Trade Balance to Exchange Rate Shock

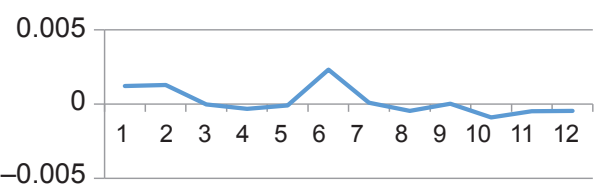

Response of Belgium Trade Balance to Exchange Rate Shock

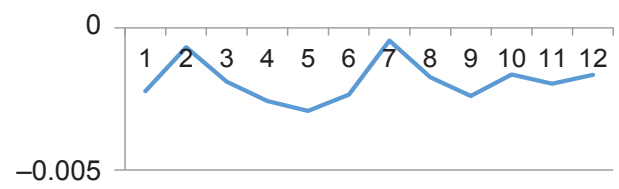

Response of Italy Trade Balance to Exchange Rate Shock

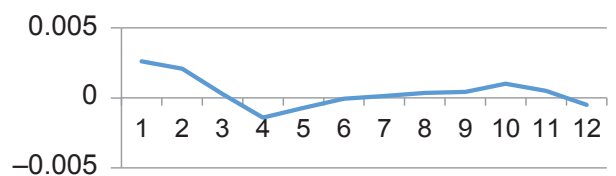

Response of UKTrade Balance

to Volatility Shock

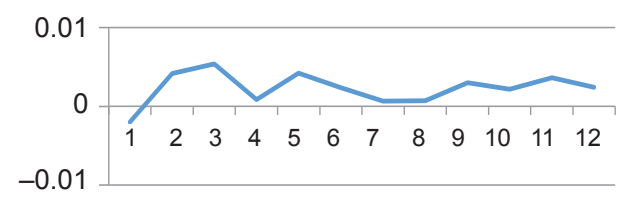

Response of Germany Trade Balance

to Volatility Shock

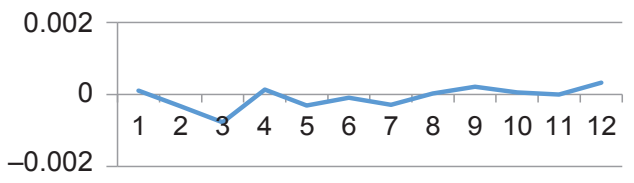

Response of France Trade Balance

to Volatility Shock

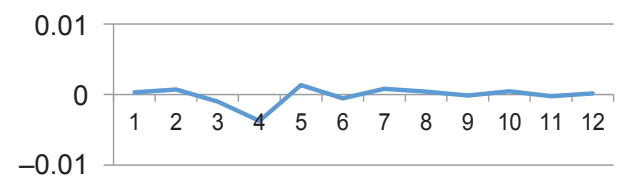

Response of Belgium Trade Balance to Volatility Shock

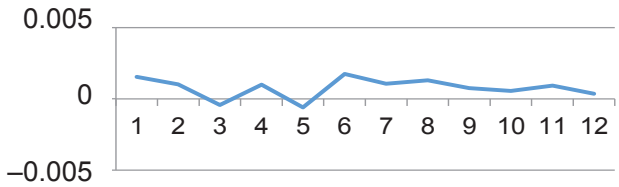

Response of ItalyTrade Balance to Volatility Shock

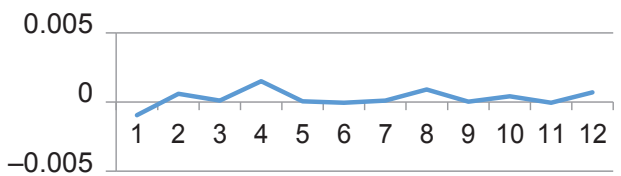


Response of Dutch Trade Balance to Exchange Rate Shock

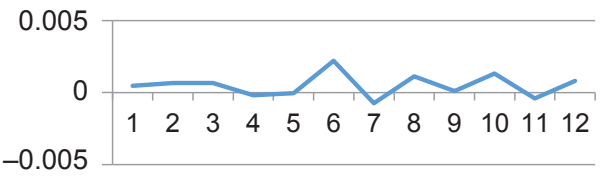

Response of Spain Trade Balance to Exchange Rate Shock

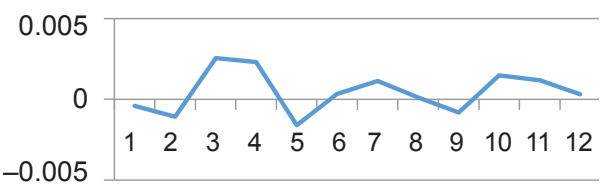

Response of Korea Trade Balance to Exchange Rate Shock

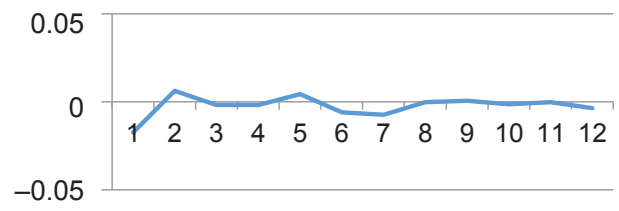

Response of Mexico Trade Balance to Exchange Rate Shock

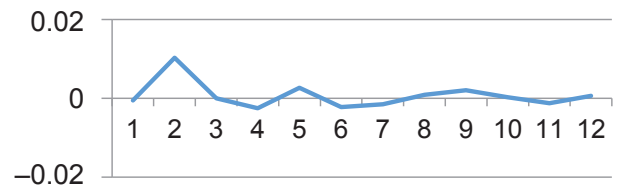

Response of Chile Trade Balance to Exchange Rate Shock

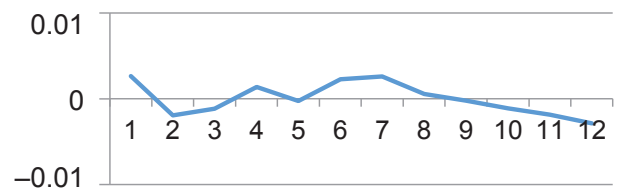

Response of DutchTrade Balance to Volatility Shock

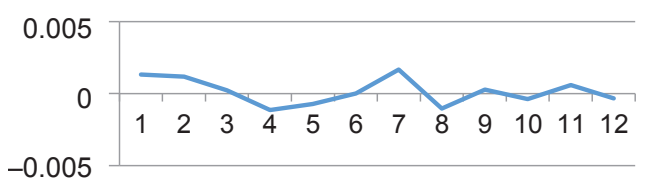

Response of Spain Trade Balance to Volatility Shock

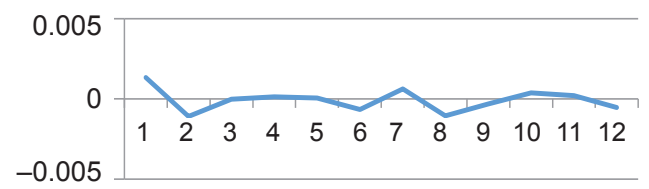

Response of Korea Trade Balance to Volatility Shock

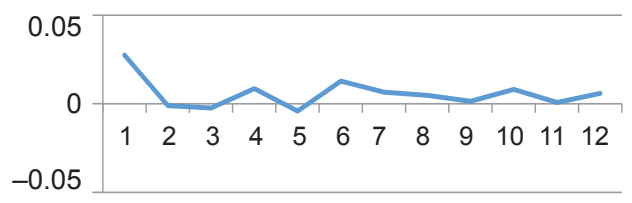

Response of Mexico Trade Balance to Volatility Shock

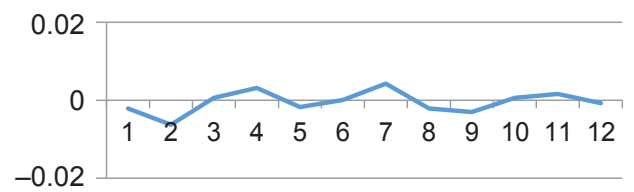

Response of Chile Trade Balance to Volatility Shock

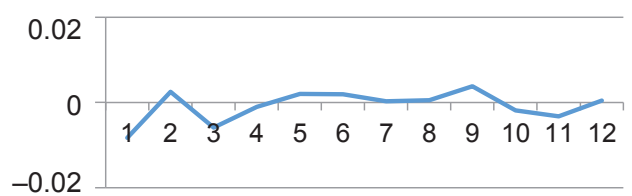


Response of Israel Trade Balance

to Exchange Rate Shock

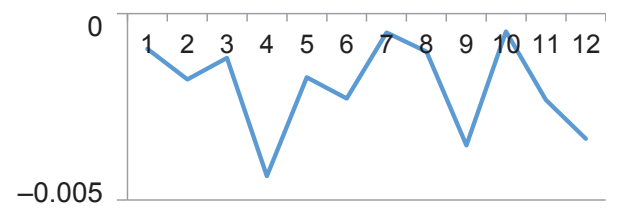

Response of China Trade Balance to Exchange Rate Shock

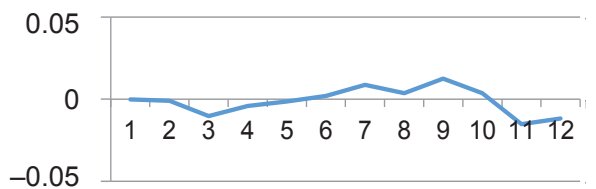

Response of India Trade Balance to Exchange Rate Shock

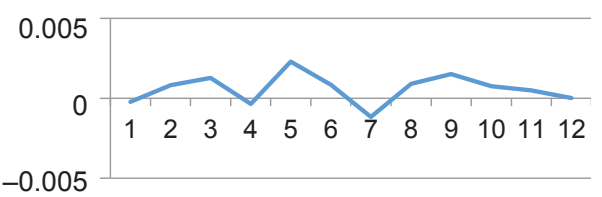

Response of Israel Trade Balance to Volatility Shock

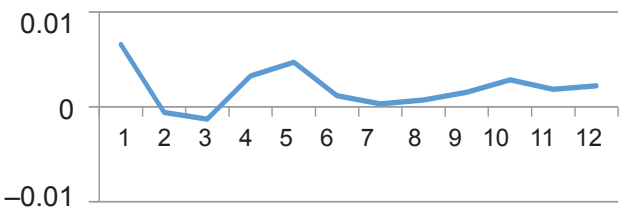

Response of China Trade Balance to Volatility Shock

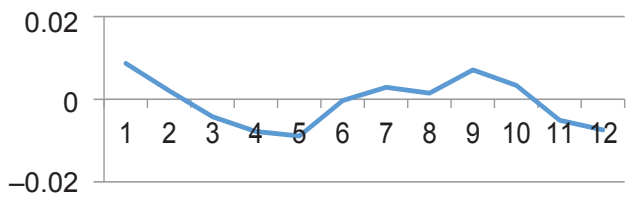

Response of India Trade Balance to Volatility Shock

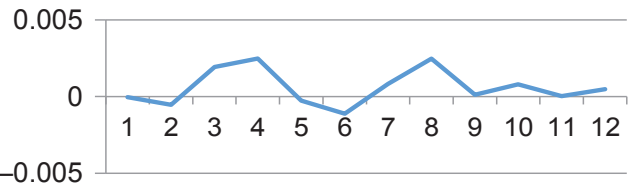


Response of USA Domestic Output to Exchange Rate Shock

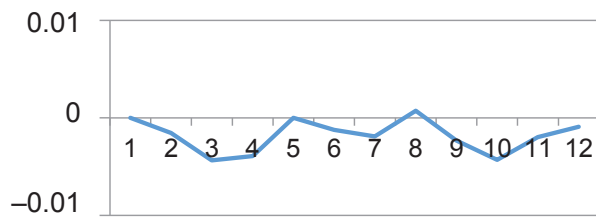

Response of Japan Domestic Output to Exchange Rate Shock

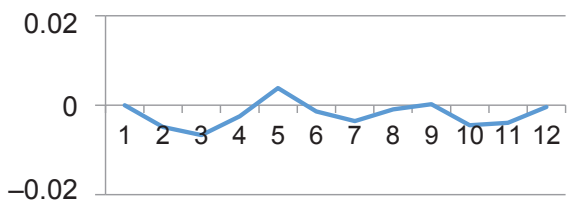

Response of Swiss Domestic Output to Exchange Rate Shock

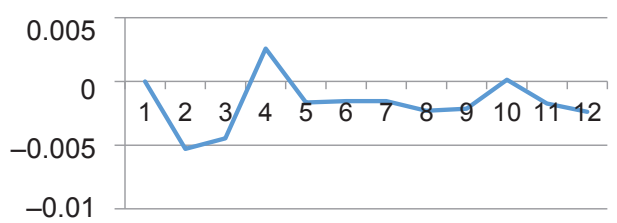

Response of Australia Domestic Output to Exchange Rate Shock

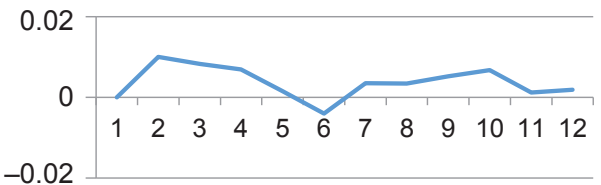

Response of USA Domestic Output to Volatility Shock

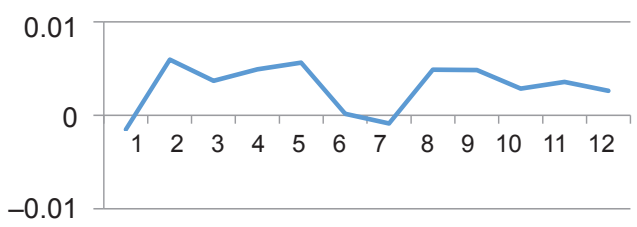

Response of Japan Domestic Output to Volatility Shock

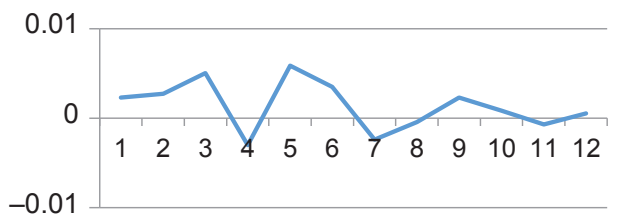

Response of Swiss Domestic Output to Volatility Shock

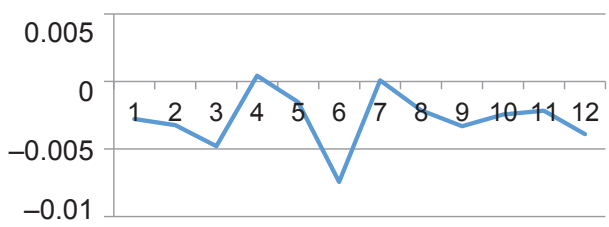

Response of Australia Domestic Output to Volatility Shock

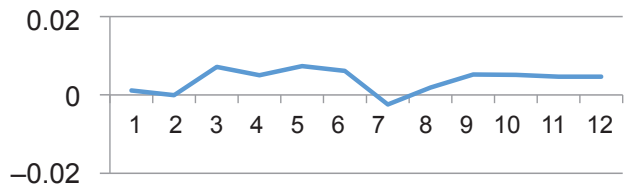


Response of Canada Domestic Output to Exchange Rate Shock

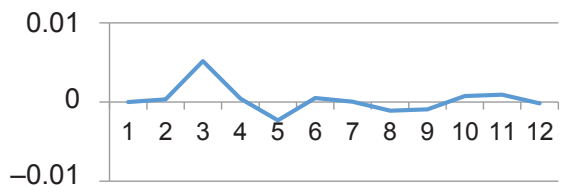

Response of UK Domestic Output to Exchange Rate Shock

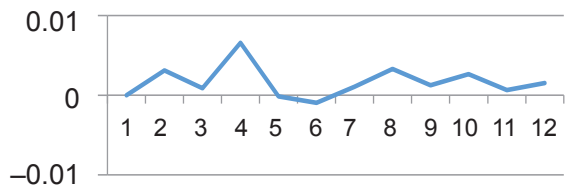

Response of Germany Domestic Output to Exchange Rate Shock

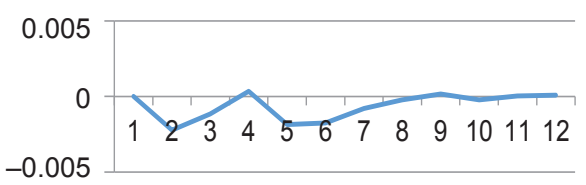

Response of France Domestic Output to Exchange Rate Shock

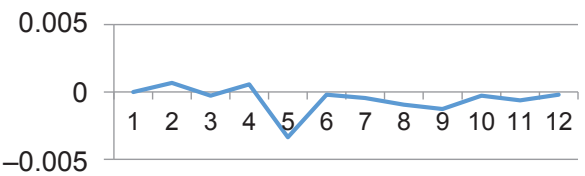

Response of Belgium Domestic Output to Exchange Rate Shock

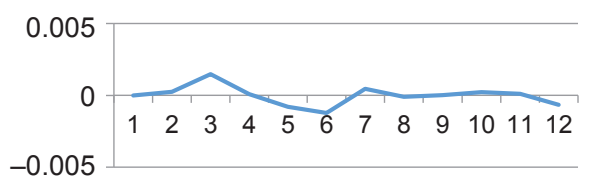

Response of Canada Domestic Output to Volatility Shock

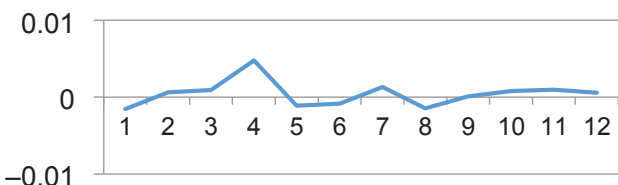

Response of UK Domestic Output to Volatility Shock

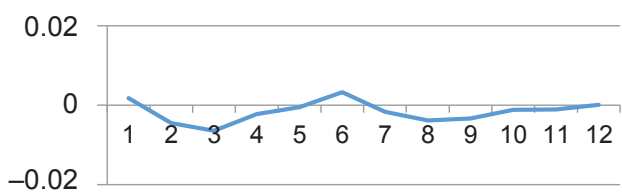

Response of Germany Domestic Output to Volatility Shock

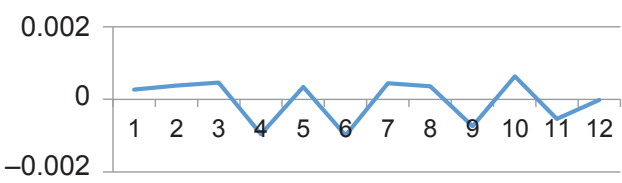

Response of France Domestic Output to Volatility Shock

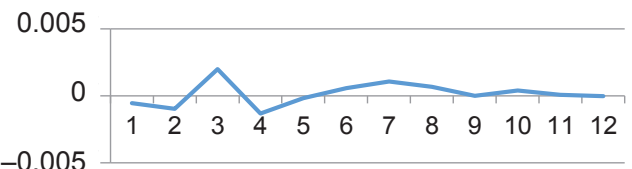

Response of Belgium Domestic Output to Volatility Shock

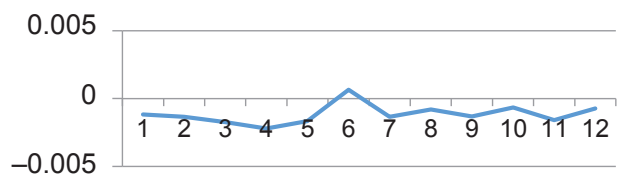


Response of Italy Domestic Output to Exchange Rate Shock

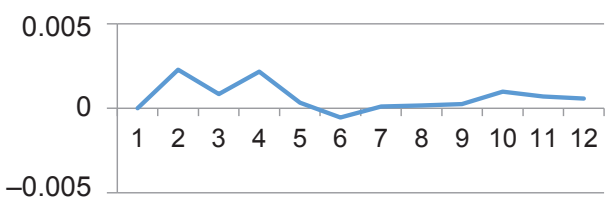

Response of Dutch Domestic Output to Exchange Rate Shock

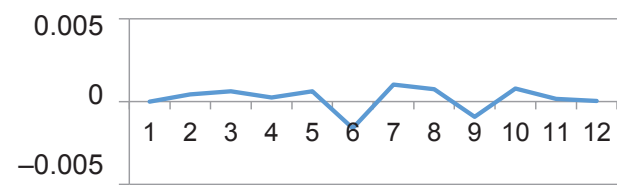

Response of Spain Domestic Output to Exchange Rate Shock

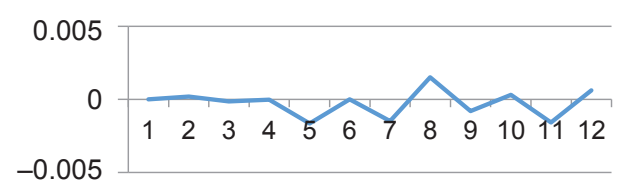

Response of Korea Domestic Output to Exchange Rate Shock

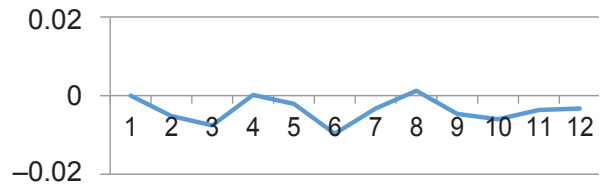

Response of Mexico Domestic Output to Exchange Rate Shock

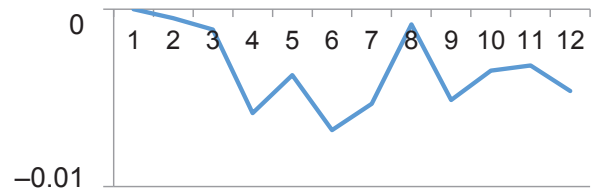

Response of Italy Domestic Output to Volatility Shock

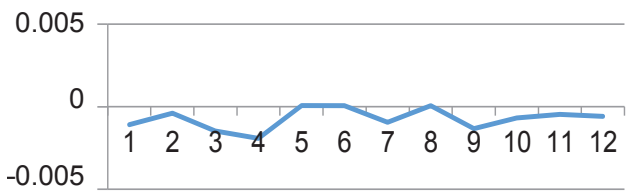

Response of Dutch Domestic Output to Volatility Shock

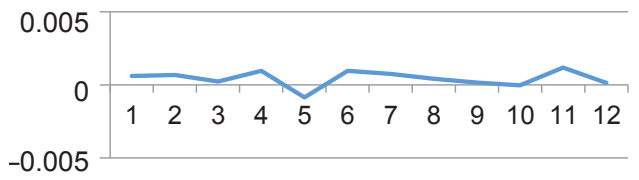

Response of Spain Domestic Output to Volatility Shock

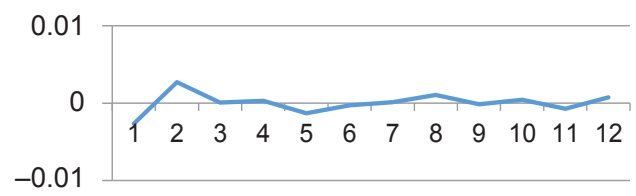

Response of Korea Domestic Output to Volatility Shock

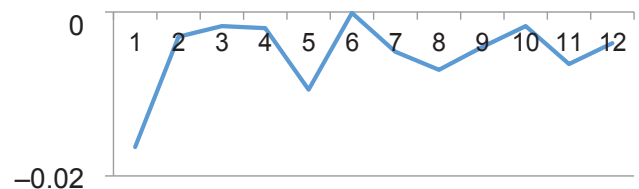

Response of Mexico Domestic Output to Volatility Shock

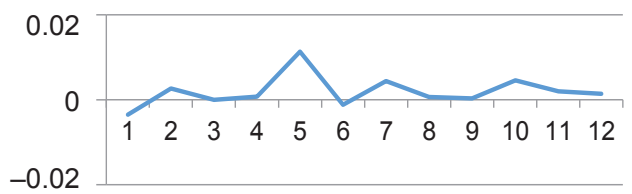




\section{Figure 2 | Continuation}

Response of Chile Domestic Output to Exchange Rate Shock

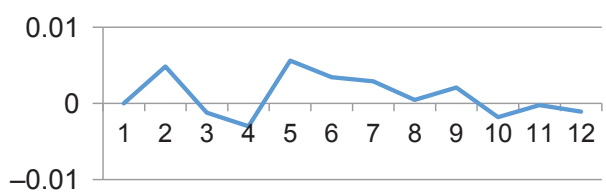

Response of Israel Domestic Output to Exchange Rate Shock

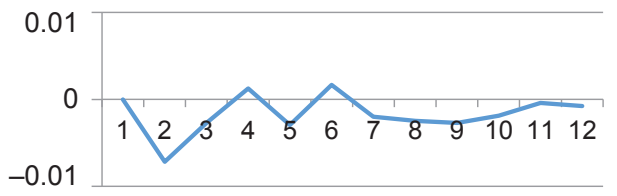

Response of China Domestic Output to Exchange Rate Shock

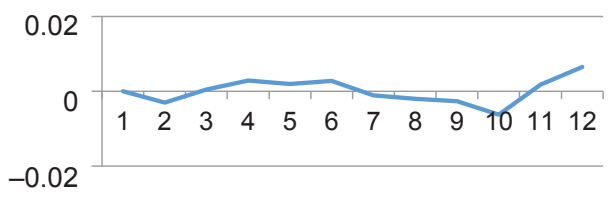

Response of India Domestic Output to Exchange Rate Shock

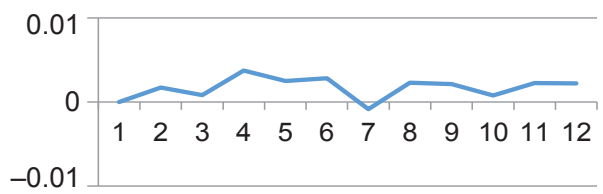

Response of Chile Domestic Output to Volatility Shock

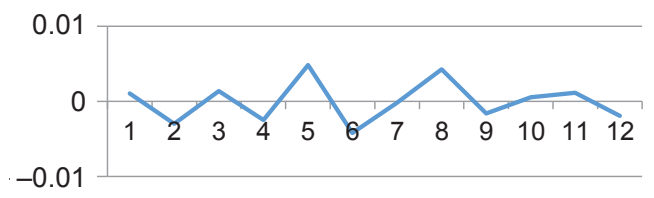

Response of Israel Domestic Output to Volatility Shock

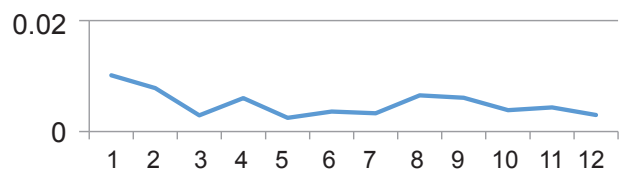

Response of China Domestic Output to Volatility Shock

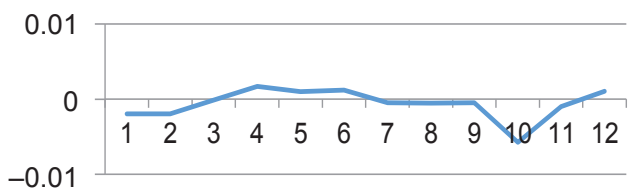

Response of India Domestic Output to Volatility Shock

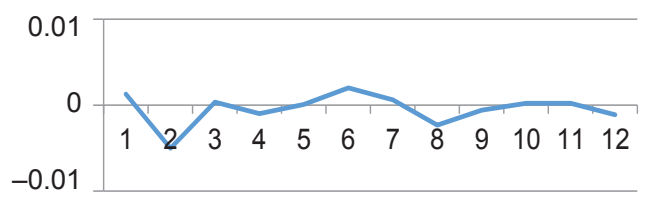


The impulse response analysis of the real effective exchange rate on trade balance in Figure 1 indicates that the real trade balances after real depreciation of currency do not follow J-curve patterns. The sets estimates of impulse response above are very different to each other. For example, in the case of the United States, the trade balance upon real depreciation deteriorates in the first quarter, and subsequently improves, reaching new equilibrium value sometime after about a year's time. This especially suggests that the responses of the trade balance to volatility shock appear to be initially negative or positive, and die out within two to five quarters (see Appendix for details).

The impulse response analysis of the real effective exchange rate on the GDP in Figure 2 indicates that depreciation is recessionary or expansionary lasting, reaching new equilibrium value sometime after about five quarters. The sets estimates of impulse response above are very different to each other. Also, the responses of the domestic economy to volatility shock appear to be initially negative or positive, and die out within two to eight quarters.

\section{Conclusion}

This paper investigates effects of the real exchange rate and its volatility on trade balance and real GDP using a set of eighteen countries, mainly OECD countries. We apply the multivariate cointegration method and employ VEC or VAR models to investigate their relationship. Results at Appendix 1 indicate a stationary long-run equilibrium relationship between the real trade balance and its determinants for the United States, Switzerland, Australia, the United Kingdom, Belgium, Italy, the Netherlands, Spain, South Korea, Mexico, Israel, and India. The Granger causality results of the trade balance and the output indicate that the direction of causation may not be only one way.

The long-run effects in the leading small open economy show that real currency depreciation leads to improvement of trade balance in the Netherlands and Korea with an exception of Mexico and Israel, while the exchange rate volatility worsens the trade balance in Korea, Mexico, and India with an exception of Australia and the Netherlands. In contrast, the short-run effects suggest that currency devaluation immediately improves the trade balance in the US and Germany in the large economy as well as Switzerland, Australia, Chile and India in the small open economy while currency depreciation immediately worsens the trade balance in the Netherland, Spain, and Korea. Also, volatility worsens the trade balance in the US, Japan, Belgium, Chile, and Spain while volatility rather improves the trade balance in Australia, Italy, the Netherlands, Korea, and Israel. This indicates that real currency depreciation leads to improvement of trade balance in most of the examined countries. With regard to the real exchange rate variability, the evidence is mixed.

Similarly, currency depreciation increases the real GDP in the UK, Germany, France, the Netherlands, Korea, and Mexico except China. This indicates that effects of the real currency devaluation on real GDP differ across countries. And the volatility rather decreases the real GDP in the United States, Japan, and China in the large economy. 
The impulse response suggests that the real trade balances after real depreciation of currency do not follow J-curve patterns. The responses of the trade balance to volatility shock appear to be initially negative or positive, and die out within two to five quarters. The responses of the domestic economy to volatility shock appear to be initially negative or positive, and die out within two to eight quarters. The sets estimates of impulse response are very different to each other. Additionally, we find that the trade balance response to devaluation shock in the major currency-owned countries could reach a new equilibrium after four to seven quarters except the Eurozone and Canada while the trade balance response to devaluation shock in the non-major currency-owned countries could reach a new equilibrium after two to three quarters except Israel. Similarly, the trade balance response to volatility shock in the major currency-owned countries could die out after three to four quarters except the Eurozone and Canada while the trade balance response to volatility shock in the non-major currency-owned countries could die out just after about two quarters. This may imply that major currency-owned countries could have different value-and-volume-effects with countries with non-major currency.

The topic of the paper is highly relevant given the fact that several open economies have resorted to the exchange rate as an additional instrument of monetary policy. The contribution of the study to the existing vast literature on exchange rate effects might be an application to a set of large economy with major currency versus large or small open economy with non-major currency. Thus, policy makers may have to consider our suggestions. 


\section{Appendix}

\section{Comparisons for Exchange Rate Effects on Trade Balance \& Output}

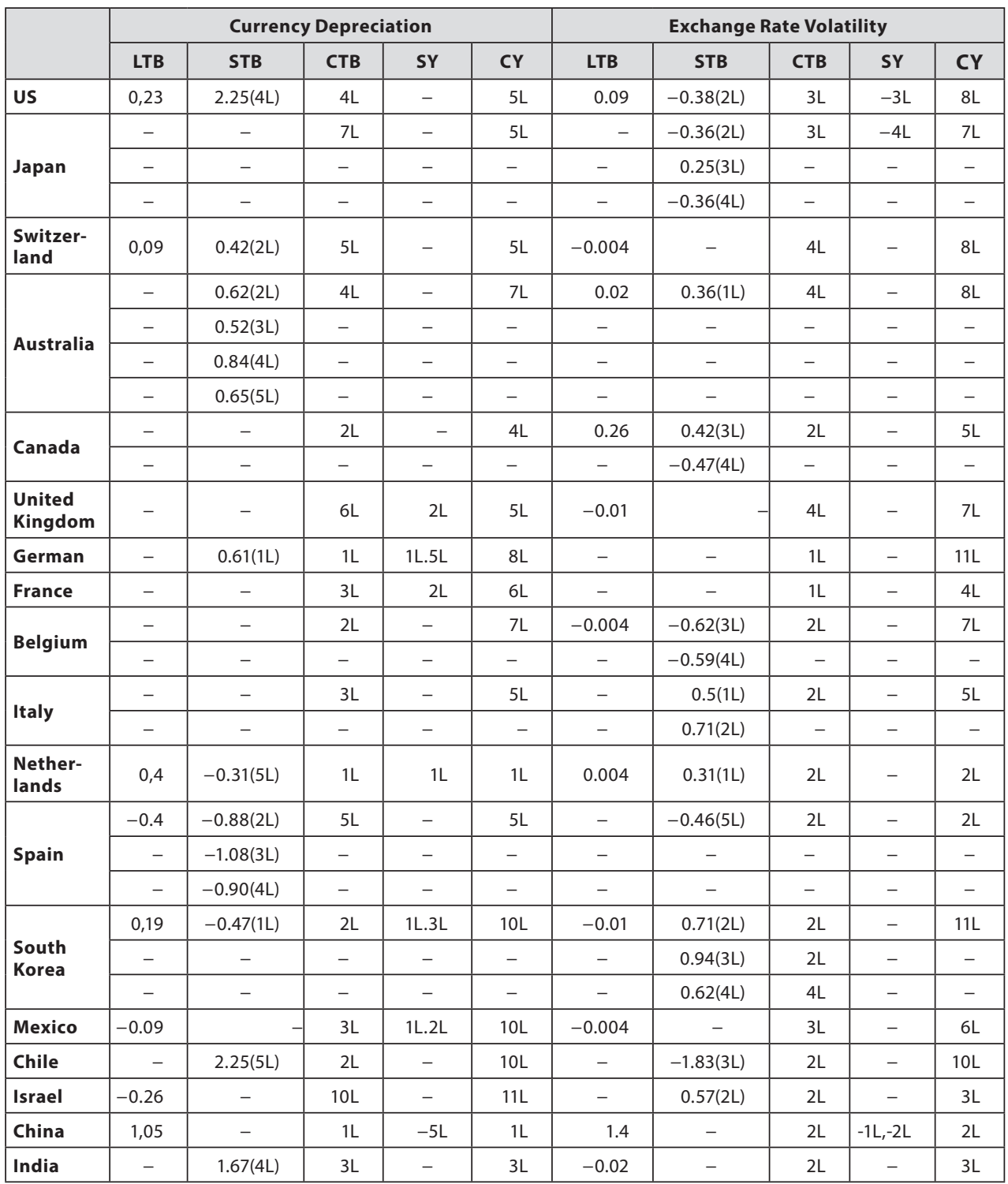

Note: The significant values are represented in about the $10 \%$ significant level. Here, $L T B=$ the trade balance change in the long run, STB = the trade balance change in the short run, CTB = the trade balance response to its shock, $S Y=$ the GDP change in the short run, $C Y=$ the GDP response to its shock. Here $L$ means the number of lags, which indicates both a significant lag in the parentheses of STB and an adjusting lags into the new equilibrium in other cases. 


\section{References}

Ali, D. A., Johari, F. and Alias, M. H. (2014). The Effect of Exchange Rate Movements on Trade Balance: a Chronological Theoretical Review. Economics Research International, 2014, 1-7, https://doi.org/10.1155/2014/893170

Auboin, M. and Ruta, M. (2011). The Relationship between Exchange Rates and International Trade: a Review of Economic Literature, WTO, Staff Working Paper ERSD-2011-17. https:// doi.org/10.1017/s1474745613000025

Backus, D. K., Kehoe, P. J., and Kydland, F. E. (1994). Dynamics of the Trade Balance and the Terms of Trade: The J-Curve? The American Economic Review, 84(1), 84-103. https:// doi.org/10.1257/aer.1994.84.issue-1

Bahmani-Oskooee, M. (1985). Devaluation and the J-curve: Some Evidence from LDCs. The Review of Economics and Statistics, 67(3), 500-504. https://doi.org/10.1162/ rest.1985.67.issue-3

Berument, H. and Pasaogullari, M. (2003). Effects of the Real Exchange Rate on Output and Inflation: Evidence from Turkey. The Developing Economies, 41(4), 401-35. https://doi. org/10.1111/deve.2003.41.issue-4

Calvo, G. A., Reinhart, C. M. (2002). Fear of Floating. The Quarterly Journal of Economics, 117(2), 379-408, https://doi.org/10.1162/qjec.2002.117.issue-2.

Choudhry, T. (2005). Exchange Rate Volatility and the United States Exports: Evidence from Canada and Japan. Journal of the Japanese and International Economies, 19(1), 51-71, https://doi.org/10.1016/j.jjie.2003.11.002

Chowdhury, A. (1993). Does Exchange Rate Variability Depress Trade Flows? Evidence from Error Correction Models. Review of Economics and Statistics, 75(4), 700-706, https://doi. org/10.1162/rest.1993.75.issue-4

Clark, P., Tamirisa, N., Wei, S. J., Sadikov, A., Zeng, L. (2004). Exchange Rate Volatility and Trade Flows-some New Evidence. International Monetary Fund, 1-131.

Cote, A. (1994). Exchange Rate Volatility and Trade: a Survey, Bank of Canada WP 94-5, 1-28.

Dickey, D. A. and Fuller, W. A. (1979). Distribution of the Estimators for Autoregressive Time Series with a Unit Root. Journal of American Statistical Association, 74(366), 427-431, https://doi.org/10.2307/2286348

Dincer, N., Kandil, M. (2011). The Effects of Exchange Rate Fluctuations on Exports: A Sectoral Analysis for Turkey. The Journal of International Trade \& Economic Development, 20(6), 809-837, https://doi.org/10.1080/09638190903137214

Engle, R. F., Granger, C. W. J. (1987). Co-integration and Error Correction: Representation, Estimation and Testing. Econometrica, 55(2), 1251-1276. https://doi.org/10.1111/ ecta.1987.issue-2

Granger, C. W. J. (1980). Testing for Causality - a Personal Viewpoint. Journal of Economic Dynamics and Control, 2, 329-352, https://doi.org/10.1016/0165-1889(80)90069-x

Johansen, S. (1991). Estimation and Hypothesis Testing of Cointegration Vectors in Gaussian Vector Autoregressive Models. Econometrica, 59(6), 1551-1580, https://doi.org/10.1111/ ecta.1991.issue-6

Johansen, S., Juselius, K. (1990). Maximum Likelihood Estimation and Inference on Cointegration with Applications to the Demand for Money. Oxford Bulletin of Economics and Statistics, 52(2), 169-210. https://doi.org/10.1111/obes.1990.issue-2 
Junz, H. B., Rhomberg, R. R. (1973). Price Competitiveness in Export Trade among Industrial Countries. American Economic Review, 63(2), 412-418,

https://doi.org/10.1257/aer.1973.63.issue-2

Haddad, M., Pancaro, C. (2010). Can Real Exchange Rate Undervaluation Boost Exports and Growth in Developing Countries? Yes, but not for Long. The World Bank Economic Premise, 20.

Hodge, D. (2005). The Effect of Exchange Rate Volatility on Trade and Employment: a Brief Review of the Literature. Human Science Research Council, June.

Kandil, M., Mirzaie, A. (2002). Exchange Rate Fluctuations and Disaggregated Economic Activity in the US: Theory and Evidence. Journal of International Money and Finance, 21(1), 1-31, https://doi.org/10.1016/S0261-5606(01)00016-X

Kandil, M., Berument, H., Dincer, N. N. (2007). The Effect of Exchange Rate Fluctuations on Economic Activity in Turkey. Journal of Asian Economics, 18(3), 466-489, https://doi. org/10.1016/j.asieco.2006.12.015

Kandil, M. (2015). The Adverse Effects of Real Exchange Rate Variability in Latin America and the Caribbean. Journal of Applied Economics, 18(1), 99-120, https://doi.org/10.1016/ s1514-0326(15)30005-2.

Kappler, M., Reisen, H., Schularick, M., Turkisch, E. (2011), The Macroeconomic Effects of Large Exchange Rate Appreciations. Organisation for Economic Co-operation and Development. France Working Paper No. 296, 1-55, https://doi.org/10.1787/5kgglsnbscbs-en

Kohler, M., Manalo, J., Perera, D. (2014). Exchange Rate Movements and Economic Activity. Reserve Bank of Australia Bulletin, March Quarter, 47-54.

Magee, S. P. (1973). Currency Contracts, Pass-through, and Devaluation. Brookings Papers on Economic Activity, 1973(1), 303-325, https://doi.org/10.2307/2534091

Moffett, M. H. (1989) The J-curve Revisited : An Empirical Examination for the United States. Journal of International Money and Finance, 8(3), 425-444, https://doi. org/10.1016/0261-5606(89)90007-7

Noland, M. (1989). Japanese Trade Elasticities and the J-curve. The Review of Economics and Statistics, 71(1), 175-179. https://doi.org/10.1162/rest.1989.71.issue-1

Petrovic, P., Gligoric, M. (2010). Exchange Rate and Trade Balance: J-curve Effect. Panoeconomicus, 57(1), 23-41, https://doi.org/10.2298/pan1001023p

Rivera-Batiz, F. L., Rivera-Batiz, L. (1989). International Finance and Open Economy Macroeconomics. New York: Macmilian Publishing Company. ISBN 978-0024005816.

Ronayne, D. (2011). Which Impulsive Response Function? The University of Warwick. Warwick Economic Research Papers No. 971.

Staiger, R. W., Sykes, A. O. (2010). Currency Manipulation and World Trade. World Trade Review, 9(4), 583-627, https://doi.org/10.1017/s1474745610000340

Tocarick, S. (2010). A Method for Calculating Export Supply and Import Demand Elasticities. International Monetary Fund. Working Paper No. 10/180, http://doi. org/10.5089/9781455202140.001

Yusoff, M. B. (2010). The Effects of Real Exchange Rate on Trade Balance and Domestic Output: a Case of Malaysia. The International Trade Journal, 24(2), 209-226, https://doi. org/10.1080/08853901003652377

Zhao, J. (2010). Does Exchange Rate Volatility Depress Trade Flows in a Small Open Economy? Evidence from New Zealand, Paper for presentation to the New Zealand Association of Economist Conference, 2010. 